\title{
Correlation and Constitutional Rights
}

Laura K. Donohue

Georgetown University Law Center, Ikdonohue@law.georgetown.edu

This paper can be downloaded free of charge from:

https://scholarship.law.georgetown.edu/facpub/2303

https://ssrn.com/abstract=3678024

Laura K. Donohue, Correlation and Constitutional Rights, in Without Trimmings: The Legal, Moral, and Political Philosophy of Matthew Kramer (Mark McBride \& Visa A.J. Kurki eds., Oxford University Press forthcoming).

This open-access article is brought to you by the Georgetown Law Library. Posted with permission of the author. Follow this and additional works at: https://scholarship.law.georgetown.edu/facpub

3 Part of the Constitutional Law Commons 


\title{
CORRELATION AND CONSTITUTIONAL RIGHTS
}

\author{
Laura K. Donohue ${ }^{1}$
}

\begin{abstract}
Skepticism among American scholars about the value of analytic legal positivism stems in part from the pervasiveness of private law in analytic jurisprudence. Wesley Hohfeld's influential framework proves little different: although he claims that the jural relations apply to constitutional entitlements, he relies on private law for their exposition. Matthew Kramer's scholarship clarifies and develops Hohfeld's framework and draws greater attention to its application in the public realm. This chapter advances the discussion by examining the application of the Hohfeld-Kramer framing to constitutional law in particular, demonstrating the weaknesses in assuming that the private law model can be sustained without more careful exposition. Such entitlements are held in res publica, with the result that the entitlement-holder also bears a duty of non-infringement. It identifies a new category of 'dignities', which act as a shield for claim-rights and highlights the nature of 'purported rights', where the state, holding the power of enforcement, structurally lacks the impetus to prosecute (its own) constitutional breach.
\end{abstract}

KeYwORDS: Constitutional analysis, constitutional law, duty, Matthew Kramer, Hohfeld, Hohfeldian analysis, immunity, rights, liberty, power, Public Law.

Over the past four decades, North American jurisprudence has shied away from Hohfeldian analytic jurisprudence in favor of natural law or positivist approaches bereft of the dominant analytic methodology. ${ }^{2}$ Neither Professor John Finnis's embrace of natural law nor Professor Ernest Weinrib's revival of Landellian formalism draw on the analytic distinctions. ${ }^{3}$ Professors Ronald Dworkin and Michael Moore eschew the same, even as Jeremy Waldron's scholarship is punctuated by outright hostility. ${ }^{4}$ Yet there is much to be gained from analytic jurisprudence. In his seminal article setting out jural relations, Hohfeld observes that how you view entitlements partly shapes constitutional and statutory decisionmaking. ${ }^{5}$ The problem is that, as an analytical matter, the terms wielded in the course of those debates often lack precision. 'Property', for instance, could mean 'things' or 'land'; or, when coupled with possession, a right to use, enjoy, or dispose of it. ${ }^{6}$ To resolve such ambiguities, Hohfeld defines entitlements in terms of their relationship to certain obligations or conditions. ${ }^{7}$

\footnotetext{
${ }^{1}$ Agnes N. Williams Research Professor and Professor of Law, Georgetown Law. Thanks are owed to Jeremy McCabe, at Georgetown Law Library, for locating many of the works on which I draw for this chapter. Mark Hanin, Visa Kurki, Mark McBride, John Mikhail, and Robin West provided helpful remarks on the text. I am further indebted to Matthew Kramer, whose tutelage and work has been foundational for my scholarship.

${ }^{2}$ See Gerald J. Postema, "Analytic Jurisprudence Confronted," in Legal Philosophy in the Twentieth Century: The Common Law World (New York: Springer, 2011), 547-75.

${ }^{3}$ See John Finnis, Natural Law and Natural Rights (Oxford: Clarendon Press, 1980) (advancing classic natural law theory); Ernest J. Weinrib, “Why Legal Formalism,” in Robert P. George ed., Natural Law Theory: Contemporary Essays (Oxford: Oxford University Press, 1992), 341 ("[I]nasmuch as [legal forms] are immanent to the juridical relationship they inform, they shed light on the traditional claim of natural law theory that law is an ordering of reason.")

${ }^{4}$ Ronald Dworkin, "Law as Interpretation," Critical Inquiry 9, no. 1 (September 1982): 179-200 (critiquing contemporary positivist jurisprudence as inadequate for ascertaining the meaning of legal propositions); Michael S. Moore, "A Natural Law Theory of Interpretation," Southern California Law Review, 58, no. 1 \& 2 (January 1985): 277-398 (arguing for a moral-realist understanding of law); Jeremy Waldron, Law and Disagreement (Oxford: Oxford University Press, 1999): 9 ("If one asks what analytic jurisprudence has offered [] to the judge, lawyer, or law professor interested in legislation, the answer is embarrassing. Even when they construct theories of interpretation, analytic legal philosophers have almost nothing to say about the structural features of legislation that distinguish the interpretation of a statute from the interpretation of a principle or a poem.").

${ }^{5}$ See Wesley Newcomb Hohfeld, "Some Fundamental Legal Conceptions as Applied in Judicial Reasoning," Yale Law Journal 23, no. 1 (November 1913): 18-20 (hereafter Hohfeld, FLC I).

${ }^{6}$ Hohfeld, FLC I, 22-23.

${ }^{7}$ See Hohfeld, 19-20.
} 
One of Professor Matthew Kramer's enduring contributions is clarifying and deepening the meaning of the resulting juridical framing and using it as a tool to advance inclusive legal positivism. ${ }^{8}$ In the process, he expands the framework's potential application. Hohfeld, borrowing from Savigny's analysis of Roman civil law, ${ }^{9}$ focuses similiter on private law. Kramer goes further, making good on Hohfeld's claims of constitutional relevance. He extends claim-right and liberty correlations to public law, thereby challenging the narrowness of Hohfeld's approach.

Kramer's scholarship demands careful attention, particularly in terms of its implications for understanding constitutional entitlements. He argues that most of the entitlements in bills of rights function as immunities - i.e., constraints on what actions the legislature can take..$^{10}$ Elsewhere, he considers privacy ${ }^{11}$ and procedural due process $^{12}$ to be claim-rights. Freedom of expression, in turn, he considers a liberty/privilege. ${ }^{13}$ Simultaneously, he considers entitlements incorporated into the First Amendment of the U.S. Constitution (amongst which we find freedom of expression) to be immunities. ${ }^{14}$

How should we understand the jural relations in regard to the rules regulating government action (and the mechanisms of judicial review) which impact individual or collective entitlements? Are they unique to certain pairings of entitlement/obligation or are they duplicative across categories? To what extent (if at all) do Hohfeld's jural relations capture constitutional entitlements?

There are similarities in how law functions in the private and public arenas, and rules in each sphere may reflect similar values. ${ }^{15}$ Nevertheless, as this chapter argues, the law acts in a very different capacity in relation to constraining state power than when it regulates relations among members of society.

In the former context, the entitlements held are neither in rem nor in personam, but in res publica. Although they tend to be referred to as individual rights, they also are collective entitlements. The resulting structure protects and places an obligation of non-infringement on the entitlement-holder. The legal relation cannot be altered, moreover, binding current generations for future times. It also sweeps non-entitlement

\footnotetext{
${ }^{8}$ See, e.g., Matthew H. Kramer, The Ethics of Capital Punishment: A Philosophical Investigation of Evil and Its Consequences (Oxford: Oxford University Press, 2011), 46 n. 12 (referring to the "notion of a legal power . . . in a standard Hohfeldian sense"); Matthew H. Kramer, Objectivity and the Rule of Law (Cambridge: Cambridge University Press, 2007), 27 ("The term 'liability' is used here in the sense assigned to that term by the American jurist Wesley Hohfeld. That is, it designates a susceptibility to a change in one's legal position."); Kramer, Where Law and Morality Meet, 127, 212 (applying a Hohfeldian analysis to the Supreme Court's exercise of a legal power and addressing Simmonds's account of Hohfeldian claim-rights); Matthew H. Kramer, In the Realm of Legal and Moral Philosophy: Critical Encounters (Basingstoke, UK: Macmillan Press, 1999), 115 (noting that "rights and duties are mutually entailing," further referring to the Hohfeldian framing throughout the book); Matthew H. Kramer, “There's Nothing Quasi about Quasi-Realism: Moral Realism as a Moral Doctrine," Journal of Ethics 21, no. 2 (June 2017): 185, 193 (using Hohfeldian distinction to respond to the potential for an error theorist to argue "that an ascription of moral permissibility entails an ascription of not-to-be-preventedness and an ascription of not-to-be-punishedness"); Kramer, Of Final Things, 78 (using "power" in the Hohfeldian sense to respond to rebut an attack on Inclusivism).

${ }^{9}$ See Friedrich Karl von Savigny, Jural Relations, or, The Roman Law of Persons as Subjects of Jural Relations: Being a Translation of the Second Book of Friedrich Karl von Savigny's System of Modern Roman Law, trans. W.H. Rattigan (London: Wildy and Sons, 1884), sec. 60 ("Every Jural Relation consists in the relation of one person to another person. ... [W] [ho can be the Bearer or Subject of a Jural Relation? This question concerns the possible Possession of Rights or the Jural Capacity, not the possible Acquisition of such rights or the Capacity of action, which will be considered in a subsequent volume $\S 106)$.”.); sec. 103 (examining how jural relations arise between and among people).

${ }^{10}$ Matthew H. Kramer, "Rights in Legal and Political Philosophy," in The Oxford Handbook of Law and Politics, eds. Keith E. Whittington, R. Daniel Kelemen, and Gregory A. Caldera (Oxford: Oxford University Press 2008), 417 (hereafter Kramer, RLPP).

${ }^{11}$ Matthew H. Kramer, "Rights Without Trimmings," in Matthew H. Kramer, N. E. Simmonds and Hillel Steiner, A Debate over Rights: Philosophical Enquiries (Oxford: Oxford University Press, 2000), 43-44 (hereafter Kramer, RWT).

12 Matthew H. Kramer, "Moral Rights and the Limits of the Ought-Implies-Can Principle: Why Impeccable Precautions Are No Excuse," Inquiry 48, no. 4 (August 2005): 328.

${ }^{13}$ Kramer, RWT, 11.

${ }^{14}$ Kramer, RLPP, 417.

${ }^{15}$ See generally Dawn Oliver, Common Values and the Public-Private Divide (London: Butterworths, 1999).
} 
holders within its protection. Constitutional rights further fall subject to complex collectives, which may lead to increased cases of genuine conflict. It may be nearly impossible to identify power-holders-a situation complicated by new and emerging technologies.

As a substantive matter, the Hohfeldian framing fails to capture a different type of entitlement, which I term 'dignities': unwritten entitlements that exist prior to the state, which act as a shield for claim-rights in much the same way that claim-rights act as a shield for liberties. Drawing on examples from First, Second, Fourth, Fifth, and Sixth Amendment jurisprudence, the chapter also identifies limits 'powers' and their application in the constitutional realm. The juridical relations, moreover, are not concerned with how an entitlement comes to be recognized, acknowledged, or created. As a result, they miss the distinction between legislatively-created and judicially-created entitlements and the relationship among them, much less how the framing should apply to rights that are not yet recognized or even foreseen, but which are said to exist. The chapter concludes by proposing a new category of 'purported rights' for situations in which the state can sidestep enforcement with impunity.

\section{Clarifying and Deepening the Hohfeldian Framing}

Hohfeld's terrain is well-trodden: he proposes four pairs of correlatives (i.e., two legal positions, each entailing the other) and four pairs of contradictories (i.e., two legal positions negating each other). See Fig. 1. Constituting his first-order relations are right/duty and privilege/no-right, and his second-order relations power/liability and immunity/disability. The result is a scheme that Kramer describes as "marvelously capacious and flexible." ${ }^{, 16} \mathrm{He}$ clarifies and deepens the framing in important ways.

\begin{tabular}{|clllll|}
\hline \multicolumn{1}{c}{} & \multicolumn{2}{c}{ First-Order Relations } & \multicolumn{2}{c|}{ Second-Order Relations } \\
\cline { 2 - 3 } Jural & Right & Privilege/liberty & & Power & Immunity \\
Correlatives & Duty & No-right & Liability & Disability \\
& & Privilege & Power & Immunity \\
Jural Opposites & Rights & Duty & Disability & Liability \\
& & & & \\
\hline
\end{tabular}

A Hohfeldian 'right' is understood in relation to its correlative 'duty', such that the invasion of a the former entails a violation of a the latter. ${ }^{17} \mathrm{~A}$ right is therefore interchangeable with a 'claim'-i.e., a right secured by law. ${ }^{18}$ The legal element is what makes a genuine right or claim enforceable. ${ }^{19}$ Thus, any breach entails the risk of incurring a (legal) penalty. Whether a claim is actually enforced is a different question.

A 'privilege', in contrast to a right, is essentially a 'liberty' to do something, free from the right or claim of others. ${ }^{20}$ In this sense, it is the opposite of a duty, where one is under an obligation to act in a certain manner. Kramer explains, "To have a liberty to engage in a certain action is to be free from any duty to eschew the action; likewise, to have a liberty to abstain from a certain action is to be free from any duty to undertake the action." 21 More succinctly, "a legal liberty consists in the absence of a legal duty." 22 The

\footnotetext{
${ }^{16}$ Kramer, RWT, 35.

${ }^{17}$ Hohfeld, 31-32; Wesley Newcomb Hohfeld, "Fundamental Legal Conceptions as Applied in Judicial Reasoning," Yale Law Journal 26, no. 8 (June 1917): 717 (hereafter Hohfeld, FLC II).

${ }^{18}$ Hohfeld, FLC I, 31-32. See also Hohfeld, FLC II, 717, n. 16; Kramer, RWT, 9 ( "A right or claim...is the legal position created through the imposing of a duty on someone else.").

${ }^{19}$ Kramer, RWT, 9.

${ }^{20}$ Hohfeld, FLC I, 55. This chapter uses 'privilege' and 'liberty' interchangeably.

${ }^{21}$ Kramer, RWT, 10.

${ }^{22}$ Kramer, RLPP, 416.
} 
absence of the an obligation, in other words, lies with the holder of the liberty - not with some other person in regard to a requirement to act, or to forbear from acting (as is the case with claim-rights).

A liberty (or privilege) correlates to the neologism 'no-right': defined by Hohfeld as the absence of a right to interfere in the activity or state of affairs related to the liberty. ${ }^{23} \mathrm{Kramer}$ refines this understanding, arguing for a distinction between a 'no-right' and 'no right'. ${ }^{24}$ The former is understood as concerning or regarding the content of the liberty: i.e., "the correlate of X's liberty to enter [] land . . is Y's no-right concerning X's entering the land." 25 The analysis thereby centers on straightforward discussion of the content of the liberty in question. Even when an individual has a no-right to halt an activity, she may have a separate privilege of interfering. ${ }^{26}$ But it is possible to have a privilege without a concomitant claim-right. The only implication is the no-right of third parties. While the law, therefore, may not provide an instrument, an individual may proceed via personal devices (and within the confines of the liberty-holder's rights). ${ }^{27}$ If $X$ has a right that $Y$ should stay off of X's land (and $Y$ the correlative duty to do so), $X$ generally also has the privilege of entering the land such that $\mathrm{Y}$ has a no-right in relation to the liberty-privilege. There is no duty of non-interference. Instead, there is merely a freedom, which may be limited in practice.

As Kramer emphasizes, rights and liberties have a different nexus: rights are specified in relation to the duty-bearer (to act or to forbear from acting), whereas liberties are specified in relation to the privilegeholder. ${ }^{28}$ The distinction between 'rights' and 'liberties' thereby partially addresses the problem of conflicting rights, with some entitlements considered rights with correlative duties and others as liberties. It is possible that $X$ may have a liberty to $\varphi$, even as $Y$ has a liberty of interfering with $X$ 's $\varphi$-ing (as long as such interference does not violate any of $X$ 's rights).

While the first-order pairings (right/duty; liberty/no-right) relate primarily to conduct, the second-order pairings (power/liability; immunity/disability) exist in relation to other legal positions - notably, those articulated in the first-order relations. ${ }^{29}$

A Hohfeldian 'power' here means the ability or capacity to effect a change in legal relations. The facts creating the conditions for the exercise of the power may be within or beyond human control. ${ }^{30}$ If $\mathrm{X}$ has a legal power, she can be understood as being entitled to exercise volitional control in the context of a certain fact-situation, such that when it occurs, she can effect a change in legal relations. ${ }^{31}$ The definition encapsulates relations between (or, in Kramer's account of collectives, among) persons, as well as the entitlements of the power-holder (i.e., the relationship of the power-holder to herself). The person "whose volitional control is paramount may be said to have the (legal) power to effect the particular change of legal relations that is involved." 32 The exercise of a legal power can generate a right-duty relationship.

A legal power is thus a legal ability, as opposed to a legal 'inability' or 'disability.' The owner of digital data, for instance, has the power to alter her own legal interest through the totality of operative facts that is

\footnotetext{
${ }^{23}$ Hohfeld, FLC I, 32-33 (“'T] he correlative of [a liberty] is a 'no-right,' there being no single term available to express the latter conception. Thus, the correlative of X's right that Y shall not enter on the land is Y's duty not to enter; but the correlative of X's [liberty to enter the land] is manifestly Y's 'no-right' that X shall not enter.")

${ }^{24}$ Matthew H. Kramer, "On No-Rights and No Rights," The American Journal of Jurisprudence," vol. 64, no. 2 (2019): 213-223, 214-217 (hereinafter ONNR).

${ }^{25}$ Kramer, 217.

${ }^{26}$ Kramer, RWT, 10.

${ }^{27}$ Kramer, 10.

${ }^{28}$ Kramer, 13-14, 109; Kramer, RLPP, 415.

${ }^{29}$ Kramer, RLPP, 416.

${ }^{30}$ Hohfeld, FLC I, 44.

${ }^{31}$ Nicholas Bamforth, "Hohfeldian Rights and Public Law," in Rights, Wrongs and Responsibilities, ed. Matthew H. Kramer (Basingstoke, UK: Palgrave, 2001), 4.

${ }^{32}$ Hohfeld, FLC I, 44.
} 
understood as a contract. Simultaneously and correlatively, she can create in others privileges and powers relating to the data. She can transfer her interest to others. If I give my call detail records to Verizon to service my mobile phone, I have created an interest in Verizon to access and to use the information. The fact that I delegate this authority to my daughter, who may have a greater understanding of the contours of what types of information technology can glean through, for instance, my use of geolocational data in using my cellphone, is of little consequence - qui facit per alium facit per se. Hohfeld explains, "The creation of an agency relation involves, inter alia, the grant of legal powers to the so-called agent, and the creation of correlative liabilities in the principal." 33

Power constitutes the opposite of a legal disability, and the correlative of legal liability. ${ }^{34}$ The latter exists where an individual is exposed to the potential exercise of a power. It can, of course, be either pleasant or unpleasant. ${ }^{35}$ Kramer replies to critiques of Hohfeld, who charge that not all liabilities correlate with powers, by noting that under the framework, "a liability is susceptibility to changes (in legal positions) that are brought about by the exercise of a power"- not general vulnerability to legal change ${ }^{36} \mathrm{He}$ observes that the power to change a legal position, moreover, is not the same as a power to preserve legal positions. ${ }^{37}$ This is an important distinction, as it recognizes that an alteration in legal positions can be brought about through no action of the power holder, underscoring that Hohfeld makes no claim to exclusivity in regard to power.

An 'immunity' in some sense parallels a privilege: it means freedom from legal power or control by others. It thereby contrasts with a power, which is some sort of affirmative control over a legal relation. ${ }^{38}$ Kramer notes that an immunity represents the negation of a liability, essentially constituting an "insusceptibility to some change in one's entitlements." ${ }^{39}$ In this manner, if X has an immunity, she cannot fall under the power of another in regard to entitlements that constitute the immunity. Y is therefore under a 'disability' (the correlative of an immunity) in regard to the exercise of a power as against the entitlement. In other words, an attempt to exercise such a power would lack legal effect.

Kramer argues that Hohfeld's Correlativity Axiom renders theoretical arguments regarding priority and precedence moot. ${ }^{40} \mathrm{He}$ writes, "Just as a slope's downward direction is not logically or existentially prior to its upward direction, a duty is not logically or existentially prior to the right with which it is correlated. The existence of each is a necessary and sufficient condition for the existence of the other." 41 The same lack of priority marks the other pairings. They are, simply, logical relations. ${ }^{42}$

The Hohfeld-Kramer exposition of entitlements enables more precise analysis of legal entitlements. ${ }^{43}$ It elucidates overbreadth. A putative claim-right without a duty, for instance, may be merely a liberty. Pari passu, discussion of an individual's entitlement to act quickly takes us to liberty considerations, even when protected by one or more rights. ${ }^{44}$ What might appear to be a right may in fact be a bundle of more specific

\footnotetext{
${ }^{33}$ Hohfeld, 46.

${ }^{34}$ Hohfeld, 44.

${ }^{35}$ Kramer, RWT, 20-21, citing Hohfeld, FLC I, 60 n. 90.

${ }^{36}$ Kramer, RWT, 102 (emphasis in original).

${ }^{37}$ Kramer, 103.

${ }^{38}$ Hohfeld, FLC I, 55.

${ }^{39}$ Kramer, RLPP, 416.

${ }^{40}$ See D. N. MacCormick, "Rights in Legislation," in Law, Morality, and Society: Essays in Honour of H.L.A. Hart, eds. P.M.S. Hacker and Joseph Raz (Oxford: Clarendon Press, 1977); Alan R. White, Rights (Oxford: Clarendon Press, 1984); Jeremy Waldron, The Right to Private Property (Oxford: Clarendon Press, 1988); Kramer, RWT, 24. See also Visa AJ Kurki, "Are Legal Positivism and the Interest Theory of Rights Compatible?" [this volume] (expressing skepticism about the Correlativity Axiom).

${ }^{41}$ Kramer, RWT, 26.

${ }^{42}$ Kramer, 35.

${ }^{43}$ See Kramer, RWT, 22-25 (attributing this to Hohfeld).

${ }^{44}$ Kramer, 29.
} 
entitlements that bear a complex relationship to each other. "The Correlativity Axiom," Kramer writes, "points to one-to-one correlations between rights and duties of the same degree of specificity. It does not point to such correlations between rights and duties of differing degrees of specificity. [] It insists that a right must have the same content and hence the same degree of specificity as the duty with which the right is correlated." ${ }^{\prime 5}$ Thus, a general right to privacy correlates with a general duty to abstain from invading itnot specific duties vis-à-vis the right holder.

From Kramer, we also gain a greater understanding of the relationship between and among entitlements. Some of the first-order entitlements apply directly to conduct and social interaction, without mediation of entitlements in the second-order category; however, all of the entitlements in the latter category apply directly to first-order relations and only indirectly to conduct and social interaction. ${ }^{46}$ First-order opposites, moreover, constitute logical 'duals', while second order relations constitute logical contradictoriesanother important distinction. ${ }^{47}$

Kramer goes beyond Hohfeld in two further respects. First, he applies the framing to moral entitlements. ${ }^{48} \mathrm{He}$ is not the first to stake this ground: in 1924, Professor Arthur Corbin argued in the Yale Law Journal that Hohfeld's "distinctions between moral rights and legal rights are identical with those between moral duties and legal duties." ${ }^{49}$ Other scholars have advanced this position. ${ }^{50}$ But Kramer uses the scheme to battle claims to legal and moral dissimilitude. One of the most well-known attacks is mounted by H.L.A. Hart, who argues, inter alia, that a distinction between the two can be drawn in regard to strict liability, which finds no purchase in the moral realm. Where an individual lacks culpability, owing to an inability to act in accordance with the demands of morality, the breach of a moral requirement may be excused. ${ }^{51}$

Kramer makes three critical moves to counter Hart. First, he invokes Hohfeld to clarify moral rights and their correlative duties. ${ }^{52}$ The framing distinguishes elements of the Remedy Principle (i.e., the necessary and sufficient conditions for coming under the sway of a remedial duty): "If and only if X holds vis-à-vis Y a moral right against Y's $\varphi$-ing, Y's $\varphi$-ing will place $Y$ under a moral obligation to $X$ to remedy the resultant situation in some way." ${ }^{53}$ Kramer next proposes that a moral remedy both acknowledges the wrongness of the action, and seeks to redress the result of the breach. This has numerous implications. A duty-bearer, for instance, has a moral obligation in certain circumstances to seek a waiver of the duty in advance of failing to uphold it. The release constitutes an anticipatory remedy. ${ }^{54}$ It is the duty-holder,

\footnotetext{
${ }^{45}$ Kramer, 42.

${ }^{46}$ Kramer, 20.

${ }^{47}$ Kramer, ONNR, 214.

${ }^{48}$ Kramer, RWT, 8-9 (noting the distinction between genuine and nominal entitlements and the potential for conflicts between duties as two exceptions).

${ }^{49}$ Arthur L. Corbin, "Rights and Duties," Yale Law Journal 33, no. 5 (March 1924): 505.

${ }^{50}$ See, e.g., Carl Wellman, Real Rights (New York: Oxford University Press, 1995); Judith Jarvis Thompson, The Realm of Rights (Cambridge, MA: Harvard University Press, 1990); L. W. Sumner, The Moral Foundations of Rights (Oxford: Clarendon Press, 1987). For critiques of this position, see Peter Westen, "Poor Wesley Hohfeld," San Diego Law Review 55, no. 2 (MayJune 2018): 449-67; Hurd and Moore, "Hohfeldian Analysis;" John Kleinig, "Human Rights, Legal Rights, and Social Change," in Human Rights, eds. Eugene Kamenka and Alice Erh-Soon Tay (New York: St Martin's Press, 1978), 36-47.

${ }^{51}$ H. L. A. Hart, The Concept of Law (Oxford: Clarendon Press, 1961), 168-76, 174. See also H. L. A. Hart, Punishment and Responsibility: Essays in the Philosophy of Law, 2nd ed. (Oxford: Oxford University Press, 2008), 35-40 (arguing that strict liability does not apply to the moral realm); Matthew H. Kramer, "Moral Rights and the Limits of the Ought-Implies-Can Principle: Why Impeccable Precautions Are No Excuse," Inquiry 48, no. 4 (August 2005): 307-55, 310 (discussing, citing, and arguing against Hart's exclusion of strict liability).

52 Kramer, "Moral Rights," 312 ("X vis-à-vis Y holds a right to Y's $\varphi$-ing if and only if Y owes a duty to X to $\varphi$ (where ' $\varphi$ ' represents any course of conduct by Y.")

${ }^{53}$ Kramer, 313. Similarly, where Y owes $\mathrm{X}$ a moral duty not to $\varphi$, then $\mathrm{Y}$ is under an obligation to remedy the situation.

${ }^{54}$ Kramer, 314.
} 
moreover, that bears the burden of remedial action. ${ }^{55}$ The critical step is the breach itself: "Y's doing or omitting to do something - his $\varphi$-ing - must be sufficient for the obligatoriness of a remedy if $Y$ is to be classifiable as a duty-bearer." 56 Thus, even if someone else supplies the remedy, the need for one is created by Y's actions. Kramer adds a distinction between exoneration (or absolution) and 'extenuation'. The latter, he proposes, refers to "some feature of a person's behavior or circumstances that lessens the gravity of a wrong that the person has committed." 57 It does not mean that the act itself was not wrong (i.e., impermissible), but blameworthiness alters.

Professor Walter Sinnott-Armstrong's scenario of missing a lunch date to save someone's life (only to later hear that the restaurant where the meeting would otherwise have occurred was bombed), provides a colorful example of extenuation. ${ }^{58}$ Under these circumstances, Kramer suggests, the morally-optimal decision to save a human life, together with the gratifying consequences of the breach, "do not completely absolve the promisor of any obligations to remedy his breach of duty, but they do very heavily extenuate that breach." ${ }^{59}$ Kramer concludes that impeccable precautions cannot fully absolve an individual of moral responsibility, even in the face of extenuating circumstances. ${ }^{60} \mathrm{He}$ proposes an example from public law: where a defendant, tried under perfectly executed criminal procedures, is deemed guilty - and serves timefor a crime he never commits. When the error is discovered, and the individual released from prison, a moral remedy is still required. Owing to the blamelessness of the systemic mechanisms, the remedy may consist only of a formal apology as an acknowledgement that a wrong has occurred. Nevertheless, a remedy has been supplied. ${ }^{61}$ Thus, while "falling short may be heavily extenuated by one's having adopted all reasonable precautions or by one's having had to avert an even worse outcome, it remains a falling short." 62

For Kramer, the moral obligation (and breach thereof) reflects the seriousness of the impact on the defendant's basic interests - in this case, liberty. ${ }^{63}$ It is in virtue of the importance of these interests that Kramer affirms the existence of strict liability in morality, although such serious interests may not always be necessary for its existence.

Here we see the second way in which Kramer draws broader implications: he applies the framing to public law in a more deliberate fashion than Hohfeld, noting how the distinctions should be understood in relation to the rights discourse. This very application, however, raises significant questions about the extent to which parallels can be drawn between private law and the public realm.

\section{Constitutional Entitlements In Res Publica}

The kinds of entitlements captured in the constitutional realm are held not just in personam or in rem, but in res publica. What this means, in a democratic state, is that the entitlement-holder and the obligationbearer at some level can be considered the same entity. This is very different than the Hohfeldian concept of a 'right', which is understood in relation to a correlative duty on others. Nor does it correspond to a Hohfeldian 'liberty' in that it entails a non-infringement obligation, for which the nexus is not on the rightholder, but on the collective state - which, under Kramer's account, may be explainable by the individual obligations of its constituent members but is not reducible to them. Unlike the other entitlements

\footnotetext{
${ }^{55}$ Kramer, 314-316.

${ }^{56}$ Kramer, 317.

${ }^{57}$ Kramer, 310.

${ }^{58}$ Walter Sinnott-Armstrong, "Moral Dilemmas and Rights," in Moral Dilemmas and Moral Theory, ed. H. E. Mason (New

York: Oxford University Press, 1996), 54-55; Kramer, "Moral Rights," 317-333.

${ }^{59}$ Kramer, "Moral Rights," 318. See also Kramer, 319.

${ }^{60}$ Kramer, "Moral Rights," 328.

${ }^{61}$ Kramer, 328.

${ }^{62}$ Kramer, 329-330.

${ }^{63}$ Kramer, 331.
} 
contemplated by Hohfeld, moreover, the breach of constitutional entitlements, as long as they exist, cannot be waived - either by the entitlement-holder or by the state as a collective. ${ }^{64}$

Hohfeld proposes that all four entitlements can be considered either paucital or multital. As a matter of first-order relations, "A paucital right, or claim, (right in personam) is either a unique right residing in a person (or group of persons) and availing against a single person (or single group of persons); or else it is one of a few fundamentally similar, yet separate, rights availing respectively against a few definite persons." ${ }^{95}$ While the primary rights may be in rem, the vindication proceedings can be in personam. ${ }^{66}$ Multital rights, in contrast, exist among three or more people. ${ }^{67}$ Hohfeld considers them an amalgamation of the rights held by individual members of the collective. ${ }^{68}$ Accordingly, "[I]nstead of there being a single right with a single correlative duty resting on all the persons against whom the right avails, there are many separate and distinct rights, actual and potential, each one of which has a correlative duty resting upon some one person." ${ }^{69}$ Hohfeld summarizes, "A right in rem, or a multital right, correctly understood, is simply one of a large number of fundamentally similar rights residing in one person; and any one of such rights has as its correlative one, and only one, of a large number of general, or common, duties - that is, fundamentally similar duties residing respectively in many different persons." 70 The same holds for a duty in rem.

From Hohfeld's exposition, it would seem that constitutional entitlements in the public law realm, ought to be considered multital, in that they are held by members of a collective - in this case, citizens of the state, as against the government. Unlike types of relationships that Hohfeld contemplates, they are held neither in personam nor in rem, but in res publica. Accordingly, they tend to be couched in terms of 'the People'. The U.S. Bill of Rights protects "the right of the people peaceably to assemble, and to petition the Government for a redress of grievances"71; "the right of the people to keep and bear Arms"72; "[t]he right of the people to be secure in their persons, houses, papers, and effects, against unreasonable searches and seizures" "73; construal of constitutional rights in a manner that does not "deny or disparage others retained by the people" "74; and reservation of "[t]he powers not delegated to the United States" for "the people."75 While such entitlements can be asserted on behalf of an individual, as an expression of their own constitutional right as held against the government, they reflect the rights of the people as a whole.

Simultaneously, courts regularly recognize private collectives, which are themselves covered by the constitutional right held by 'the People'. In NAACP v. Alabama, a unanimous Supreme Court thus held that the right to free association exempted the group from being forced to turn its membership lists over to the state government. ${ }^{76}$ Justice John M. Harlan wrote, "Immunity from state scrutiny of petitioner's membership lists is here so related to the right of petitioner's members to pursue their lawful private interests privately and to associate freely with others in doing so as to come within the protection of the

\footnotetext{
${ }^{64}$ But see Visa Kurki, "Hohfeldian Infinities: Why Not to Worry," Res Publica, 23, 137-146 (2017) (arguing that non-waivable entitlements do not present a concern within the Hohfeldian structure).

${ }^{65}$ Hohfeld, FLC II, 718.

${ }^{66}$ Hohfeld, 763. He adds, "While the word 'paucital' is suggested as the generic term to cover all rights in personam, the word 'unital' would be available to denote that particular kind of right in personam that is 'unique' and 'uncompanioned." Hohfeld, 718 n. 18.

${ }^{67}$ See generally Hohfeld, 716-717.

${ }^{68}$ Hohfeld, 718 (“A multital right, or claim, (right in rem) is always one of a large class of fundamentally similar yet separate rights, actual and potential, residing in a single person (or single groups of persons) but availing respectively against persons constituting a very large and indefinite class of people.")

${ }^{69}$ Hohfeld, 742.

${ }^{70}$ Hohfeld, 745 .

${ }^{71}$ U.S. Const., amend. I.

${ }^{72}$ U.S. Const., amend II.

${ }^{73}$ U.S. Const., amend. IV.

${ }^{74}$ U.S. Const., amend. IX.

${ }^{75}$ U.S. Const., amend. X.

${ }^{76}$ NAACP v. Alabama, 357 U.S. 449 (1958).
} 
Fourteenth Amendment." "77 While the right to free association could be explained by the rights of constituent members, the NAACP was entitled to protect its members' associational privacy.

These same entitlements are held, too, by the individuals who make up 'the People' - namely, citizens. Were the Trump Administration to forbid me from peacefully protesting as part of the Black Lives Matter movement, my individual (constitutional) right to free expression would have been violated as a consequence of the obligation placed on the government in the First Amendment to abstain from infringing the collective free speech of 'the People.'

This carries significant implications. To the extent that democratic governance means that citizens also constitute the state, the entitlement-holder simultaneously acts as the one in whom the duty of noninterference resides. The collective right in question is constituted in part by the individual rights of the citizens, who also hold the organs of state power in their hands. They are thus under a duty to refrain from interference in (their own) rights. This is a very different legal relationship than the one contemplated by Hohfeld-Kramer framing, wherein a right exists on the basis of a duty held by another.

It appears, then, that constitutional entitlements do not fit squarely within the right/duty axis. No more so do they fall within the liberty/no-right correlative. The latter speaks to a freedom or privilege, with the scope defined in terms of the liberty-holder. A constitutional entitlement, in contrast, carries with it an obligation of non-infringement, both to the entitlement-holder and to the state-which, under Kramer's account, as a collective, both incorporates and goes beyond its constituent parts.

Kramer agrees with Hohfeld insofar as jural relations extend to corporate entitlements. ${ }^{78}$ A claim right (or duty) may be held by a particular person (or, in the context of constitutional rights, group of persons), against another person (or group of persons). Because of the potential for multiple rights (or duties), any claim-right (or duty) could, potentially, exist alongside other claim-rights (or duties) held by the same individual in the same context. ${ }^{79}$ Kramer goes on to suggest that collectives are not just reducible to claims about the entitlement held by each member of the collective. Instead, they reflect a set of entitlements held by one or more people. In his words, "reducibility does not amount to straightforward homologousness." 80 Individuals have certain entitlements in the context of the group and not just as a manifestation of their own, individualized entitlement. He extrapolates, "Once we have grasped that a collectivity's legal positions are quite as real as an individual's legal positions, we can submit that any public duty is owed to a collectivity (the state, the nation, the community) which holds the correlative right." 81

Kramer's insight is that Hohfeld confuses explicability with reducibility and fictitiousness. On the one hand, we can understand corporate entitlement by looking at the individual entitlements via which it operates; however, this doesn't strip away the meaning (or reality) of the corporate entitlement as a whole. ${ }^{82}$ Statements about a network of individually-held rights do not necessarily imply the existence (or absence) of a collective right. Something more is needed. Accordingly, where a collective has a legal protection, it can be explained through individual entitlements and their relationship to correlative obligations/conditions, but it cannot be reduced to that. ${ }^{83}$ Kramer writes, "An account focused purely on individuals' entitlements can in principle expound fully the ways in which any corporate entitlements operate, but cannot per se fully

\footnotetext{
${ }^{77} N A A C P, 357$ U.S. at 466.

${ }^{78}$ Kramer, RWT, 53-54.

${ }^{79}$ Kramer, 9-10.

${ }^{80}$ Kramer, 51.

${ }^{81}$ Kramer, 29.

${ }^{82}$ Kramer, 51.

${ }^{83}$ Kramer, GRR, 46.
} 
expound the effects which the operations of the corporate entitlements bring about." ${ }^{84}$ The interests of the collective are both independent of and reliant on the interests of its constituent members. ${ }^{85}$

One of the most consistent characteristics of the relationship entailed in constitutional rights is that the state, as an entity (like the citizens), also is under an obligation of non-infringement. This obligation, moreover, unlike the first order relations discussed by Hohfeld, cannot be altered. In other words, the entire point of a constitutional right, (as opposed, for instance, to a private law claim-right), is that the right holder cannot waive it against his duty-bound self. That I have a right to speech as held against the government's duty of non-interference means that I cannot, in my sovereign capacity, vote to restrict that right, either against myself or future generations. ${ }^{86}$ Further, the constitution establishes entitlements for future generations. The holding of legal rights by people not yet born "consists in the owing of legal duties to them by present-day people. ${ }^{" 87}$ Both the legal duty and the legal right are held in the present. ${ }^{88}$

One response to this argument might be to note that the constitution itself could be altered. This was one of the critical contributions of the document forged in 1787: that it allowed for its own amendment. But this assertion rather sidesteps the point, which is that as long as the jural relation exists, the entitlement operates, regardless of whether citizens or the state would prefer to see it set aside.

The Kramer-Hohfeldian framing also misses ways in which constitutional rights act as an umbrella over non-right holders - a form of transferred entitlement. Nor does it capture the (associated) extended obligation in res publica. For Kramer, "A strict right-duty correlation . . . characterize[s] every public duty along with every private duty; the only difference is that each public duty correlates with a collective right only, whereas each private duty correlates with an individual right. The party wronged by a breach of a public duty is the political grouping that holds the correlative right." ${ }^{\circ 9}$ Certain constitutional rights, however, may be extended beyond the constitutional right-holder, to protect others.

In 2018, for instance, the state of California enacted the California Consumer Privacy Act. ${ }^{90}$ This statute gives consumers greater control over their personal data, securing the right to know what is being collected (and how it is being employed and shared), the right to delete certain personal information, the right to optout of the sale of the information; and the right to non-discrimination for deciding to exercise their rights under the CCPA. The duty to abide by the statute's requirements is imposed on all entities who collect Californians' private data. In the process, the state has created claim-rights for all consumers who use those businesses goods and services. That collective right cannot be explained just as a function of the rights held by Californians - although that is the grounds on which the duty is constructed. Non-Californians do not constitute the collective: nevertheless, they hold the rights by virtue of those entitlements secured for those living in the Golden State.

While the example is from private law, corollaries can be found in the constitutional realm: the right of 'the People' in the First and Fourth Amendments extends to non-citizens on U.S. soil. Even those illegally in the country have the benefit of the rights so conveyed-despite not being a constitutive part of 'the People' as established by the preamble of the Constitution.

\footnotetext{
${ }^{84}$ Kramer, 46.

${ }^{85}$ Kramer, 46.

${ }^{86}$ Kramer recognizes that right-holders and duty-bearers do not need to be contemporaneous for the right-holding and duty-

bearing to be so. Kramer, "Getting Rights Right," in Rights, Wrongs and Responsibilities, ed. Matthew H. Kramer (Basingstoke,

UK: Palgrave, 2001), 54-55 (hereafter Kramer, GRR).

${ }^{87}$ Kramer, 54.

${ }^{88}$ Kramer, 54-55.

${ }^{89}$ Kramer, RWT, 29.

${ }^{90}$ California Consumer Privacy Act of 2018, 2018 Cal. Stat. 1807.
} 
The point flows the other way too, in that a reduction in rights held by a particular set of individuals may bring with it a reduction in rights held by others, outside of the collective to which the rights relate. In 2008 , for instance, Congress changed its foreign intelligence law to allow for the collection overseas of communications among entities reasonably believed to be non-U.S. persons and outside the United States. ${ }^{91}$ The problem is that by virtue of how the Internet functions, multi-communication transactions collected under the law included tens of thousands of entirely domestic communications as well. ${ }^{92}$ The result was that the narrowing of the collective rights of non-U.S. Persons overseas also narrowed the collective rights of U.S. persons on domestic soil. These types of legal relationships, however, are not captured by the Hohfeldian jural relations. The establishment of citizen-rights entails the establishment of non-citizensrights, and a duplication of duty vis-à-vis non-citizens, just as the narrowing of non-citizen-rights entails the narrowing of citizen-rights, with the same corresponding obligation on the state. A secondary legal relation, echoing the establishment of the original claim-right vis-à-vis citizens (or non-citizens) exists.

\section{Complex Collectives}

Not only do multiple collectives constitute society (which carries implications for entitlement-holders), but multiple collectives constitute the state, impacting the number and structure of those on whom an obligation may rest. It creates a situation ripe for genuine conflict. Complex collectives in a public law context, moreover, are especially prominent in the realm of second-order relations: who holds a power may be very difficult to ascertain - a problem exacerbated by new and emerging technologies.

Recognition of multiple duty-holders for protection of asserted claim-rights is an integral part of AngloAmerican jurisprudence. In the $17^{\text {th }}$ Century, equity famously triumphed over common law in the clash between the Lord Chancellor (Thomas Edgerton, Lord Ellesmere) and the Chief Justice of the King's Bench, Sir Edward Coke. ${ }^{93}$ Injunctions were being granted in Chancery that prevented common law judgments from going into effect. James I, through his attorneys general, came down on the side of Chancery. The systems provided two distinct sources of rights. ${ }^{94}$ Both were judicial in nature, and both generated claim-rights on behalf of British subjects and the Crown, as well as correlative duties to those rights.

Citizens in democratic regimes are subject to multiple executive and legislative collectives, with jural relations dictated by group membership, even within the same collective entity. The U.S. Constitution, for instance, recognizes dual sovereignty: powers not provided (exclusively) to the federal government are retained by the states, with both the federal government and the states acting on the People. ${ }^{95}$ This means that state executives and legislative bodies also act on citizens who have membership in the federal government.

\footnotetext{
${ }^{91}$ FISA Amendments Act of 2008, Pub. L. No. 110-261, 122 Stat. 2436.

92 See Memorandum Opinion and Order, [REDACTED], No. [REDACTED], GID.C.00073, at 41 (FISA Ct. Oct. 3, 2011) (Bates, J.), https://repository.library.georgetown.edu/handle/10822/1052732.

${ }^{93}$ Henry VIII rewarded Lord Audley for securing the trial and execution of Anne Boleyn by awarding him land in Cambridge. Magdalene College, which inherited the land, sold it, enabling the Earl of Oxford to later purchase it. Magdalene brought suit to regain the property. Earl of Oxford Case (1615) 21 Eng. Rep. 485.

94 Supreme Court of Judicature Act 1873, 36 \& 37 Vict. c. 66n (consolidating the Court of Chancery, the Court of Queen's Bench, the Court of Common Pleas, the Court of Exchequer, the High Court of Admiralty, the Court of Probate, and the Court of Divorce and Matrimonial Causes into one High Court); Supreme Court of Judicature Act 1875, 38 \& 39 Vict. c. 77.

${ }^{95}$ United States v. Lanza, 260 U.S. 377, 382 (1922) ("We have here two sovereignties, deriving power from different sources, capable of dealing with the same subject-matter within the same territory. . . Each government in determining what shall be an offense against its peace and dignity is exercising its own sovereignty, not that of the other."); Gamble v. United States, 139 S. Ct. 1960, 1965 (2019) (“'W]here there are two sovereigns, there are two laws, and two 'offences.'”). See also Abbate v. United States, 359 U.S. 187, 195 (1959); Bartkus v. Illinois, 359 U.S. 121, 138 (1959)
} 
The existence of two entities simultaneously serving in a sovereign capacity compounds the risk that entitlements and obligations clash. Kramer does recognize that within the Hohfeldian universe, conflicting rights and duties are possible. ${ }^{96}$ While it may appear that a contradiction between being duty-bound to do $\varphi$ and being duty-bound to refrain from $\varphi$-ing, it is not in fact a contradiction. Both things can be true. A genuine contradiction occurs only where a person has a duty to $\varphi$ and, simultaneously, liberty-right to abstain from $\varphi$-ing. ${ }^{97}$ Further, if $\mathrm{Y}$ has a duty to act, then $\mathrm{Y}$ does not have the privilege of not acting. Similarly, if $\mathrm{Y}$ has a duty not to interfere, $\mathrm{Y}$ does not have a liberty to interfere. ${ }^{98}$ Kramer distinguishes between legal obligations in conflict but not in contradiction: "Though the fulfilment of either one must rule out the fulfilment of the other, the existence of either one does not in any way preclude the existence of the other. This non-contradictoriness is one main feature of jural logic (with its categories of 'permissibility', 'impermissibility', and 'obligatoriness') that prevents it from being collapsed into modal logic (with its categories of 'possibility', 'impossibility', and 'necessity')." 99

As a matter of constitutional rights, priority or precedence is settled by appeal to the structure. The delineation in Article I(8) of categorical subject-matter priority, together with the Supremacy Clause, go some way towards resolving matters where there is a genuine conflict. But they do not settle all questions. Perhaps no better example can be brought than in the realm of drugs. As of the time of writing, 33 states and the District of Columbia have legalized medical marijuana. ${ }^{100}$ Until the 2018, however, it was illegal to possess, use, or buy cannabis anywhere in the United States. ${ }^{101}$ In Gonzales v. Raich, the Supreme Court came down firmly on the side of the federal government, ruling its ability to regulate private consumption of marijuana as within federal Commerce Clause powers. ${ }^{102}$ Not only did a number of states largely ignore the ruling, but in 2013 the Deputy Attorney General sent a memorandum to all United States Attorneys indicating that the U.S. Department of Justice would not be enforcing the law in states that had legalized marijuana and implemented an effective regulatory system. ${ }^{103}$

Under the Hohfeldian analysis, for citizens, the conditions do not represent an instance of noncontradictoriness but, rather, possible contradiction. Oregonians are not under both a duty to consume 24 ounces of medical marijuana (the amount allowed by state law) and a duty not to consume any marijuana (under federal law). Instead, under state law, they are permitted to consume marijuana (whereas under federal law, they are not).

For prosecutors, however, a contradiction exists: they both have a duty to enforce the existing law (which forbids marijuana in all 50 states and imposes criminal penalties for its possession) and a duty, according to the Attorney General's memorandum, not to enforce the existing law. The reason they are in this position is, in part, because of the tension inherent in dual sovereignty.

The problem of multiples in the public law context extends to second order relations. Consider powers. Kramer posits that "the exercise of a genuine legal power always occurs through a volitional act or forbearance of some sort." ${ }^{104}$ This claim falls rather short of explaining the relationship among power holders (whose actions or forbearance alters a claim-right), as well as situations in which no cognitive act

\footnotetext{
${ }^{96}$ Kramer, RWT, at 19-20.

${ }^{97}$ Kramer, 13.

${ }^{98}$ Kramer, 13.

${ }^{99}$ Kramer, 19.

${ }^{100}$ See Legal Medical Marijuana States and DC: Llaws, Fees, and Possession Limits, ProCon.org, https://medicalmarijuana.procon.org/legal-medical-marijuana-states-and-dc/.

${ }^{101}$ Controlled Substances Act of 1970, 21 U.S.C. 801 et seq.

102 Gonzales v. Raich, 545 U.S. 1 (2005).

${ }^{103}$ Memorandum from James M. Cole, Deputy Attorney General, Guidance Regarding Marijuana Enforcement, Aug. 29, 2013, https://www.justice.gov/iso/opa/resources/3052013829132756857467.pdf.

${ }^{104}$ Kramer, GRR, 58.
} 
occurs. The change in a claim-right-particularly when held against the government in a public law context—often entails complex legal relations.

On September 30, 2011, for instance, a Central Intelligence Agency (CIA) drone strike in Yemen killed Shaykh Anwar Aulaqi, an American citizen. ${ }^{105}$ The attack also killed Samir Khan, another U.S. citizen in the vehicle. ${ }^{106}$ Two weeks later, a second drone strike on an open air restaurant killed Aulaqi's 16 year old son, Abdulrahman, and six others. ${ }^{107}$ Both prior and subsequent to these acts, Aulaqi, Khan, and others' claim-rights had been altered. Was a 'power', in a Hohfeldian sense, exercised?

Let's first focus on Anwar Aulaqi. More than a year before he was killed, the U.S. Department of the Treasury determined that he was a leader of al-Qa'ida in the Arab Peninsula (AQAP), and designated him as a Specially Designated Global Terrorist under Executive Order 13224. ${ }^{108}$ The decision was based in significant measure on testimony provided by Umar Farouk Abdulmutallab, who had tried to light an explosive device while flying from Amsterdam to Detroit on Christmas Day, 2009. ${ }^{109}$ In a separate action, U.S. Joint Special Operations command (JSOC) placed Aulaqi on a military kill list. ${ }^{110}$ Leon Panetta, the Director of the CIA, and Admiral William H. McRaven, Commander of JSOC, allegedly played a central role in adding his name to the targeting list. ${ }^{111}$ In yet another act, on February 19, 2010, the Department of Justice Office of Legal Counsel issued a memorandum laying out the legal justification for the use of lethal force against Aulaqi, concluding that a drone strike would violate neither Executive Order 12333, which prohibits assassination, "or any applicable constitutional limitations due to [his] United Sates citizenship." 112 Separately, upon hearing that his son had been placed on the kill list, Nasser Al-Aulaqi filed suit to enjoin the government from carrying out the attack unless his son presented an imminent threat to human life and there were no other option but lethal force to stop him. ${ }^{113}$ The military moved to dismiss the complaint based on state secrets - an assertion supported by declarations made by the Director of National Intelligence, James Clapper; the Secretary of Defense, Robert Gates; and Panetta. ${ }^{114}$ Judge John Bates dismissed the case based on Aulaqi's father's lack of standing to assert his son's constitutional rights. ${ }^{115}$ Finally, after Aulaqi's killing, the U.S. Department of Justice developed a White Paper laying out three conditions for which the targeting of a U.S. citizen in a leadership capacity in al-Qa'ida, or an associated force, would be lawful: "(1) an informed, high-level official of the U.S. government has determined that the targeted individual poses an imminent threat of violent attack against the United States; (2) capture is infeasible, and the United States continues to monitor whether capture becomes feasible; and (3) the operation would be conducted in a manner consistent with applicable law of war principles."116

\footnotetext{
105 Al-Aulaqi v. Panetta, 35 F.Supp. 3d 56 (D.D.C. 2014). See also Def. Resp. to May 22, 2013 Order [Dkt. 26], Ex. 1 [Dkt. 261], Letter from AG Holder (May 22, 2013) (AG Letter) at 1-2; see also id., Ex. 2 [Dkt. 26-2], Remarks by President Obama at the National Defense University (May 23, 2013) (President Obama Speech) at 9-10 (President Barak Obama and Attorney General Eric Holder admitting to the targeting and killing of Aulaki).

${ }^{106}$ Al-Aulaqi v. Panetta, 35 F.Supp. 3d 56 (D.D.C. 2014).

${ }^{107} \mathrm{Id}$.

${ }^{108}$ Exec. Order 13224, Sept. 23, 2001 (issued pursuant to the International Economic Powers Act, 50 U.S.C. 1701-1706); Designation of Anwar Al-Aulaqi Pursuant to Executive Order 13224 and Global Terrorism Sanctions Regulations, 75 Fed.Reg. 43,233-01 (July 23, 2010) (publically announced July 12, 2010).

${ }^{109}$ Al-Aulaqi v. Panetta, 35 F.Supp. 3d 56 (D.D.C. 2014). See also United States v. Abdulmutallab, 739 F.3d 891 (6 $6^{\text {th }}$ Cir.2014).

${ }^{110}$ Dana Priest, U.S. Military Teams, Intelligence Deeply Involved in Aiding Yemen on Strikes, Wash. Post, Jan. 27, 2010; cited in Al-Aulaqi v. Panetta, 35 F.Supp. 3d 56 (D.D.C. 2014).

${ }^{111}$ Charlie Savage, Secret U.S. Memo Made Legal Case to Kill a Citizen, New York Times, Oct. 8, 2011; cited in Al-Aulaqi v. Panetta, 35 F.Supp. 3d 56 (D.D.C. 2014).

112 Memorandum for the Attorney General, Re: Lethal Operation Against Shaykh Anwar Aulaqi, Feb. 19, 2010, https://www.nytimes.com/interactive/2014/08/16/us/16firstolcawlakimemo.html.

${ }_{113}$ Al-Aulaki v. Obama, Civ. No. 10-1469, 2010 WLL 3478666 (D.D.C.).

114 Al-Aulaqi v. Panetta, 35 F.Supp. 3d 56 (D.D.C. 2014).

115 Al-Aullaqi v. Obama, 727 F.Supp.2d 1, $52-54$ (D.D.C.2010).

116 Dep't of Justice White Paper, Lawfulness of a Lethal Operation Directed Against a U.S. Citizen Who Is a Senior Operational Leader of Al-Qa'ida or An Associated Force, (Nov. 8, 2011 draft), http://bit.ly/Wv7Cdh (last visited Apr. 4, 2014).
} 
Each of these events - the determination by Treasury that Aulaqi was a member of AQAP; his placement on the military kill list; the dismissal of his father's suit; the unchallenged declarations made by political appointees; the President's personal decision to order the strike; the CIA's actual carrying out of the order; and DOJ's subsequent White Paper providing an after-the-fact justification - essentially waived Aulaki's Fifth Amendment due process rights, as well as his claim-right against bodily assault.

Which of them were necessary to erosion of the claim rights? Which were sufficient? Which action amounted to an exercise of the power? Was it even an exercise of power in a Hohfeldian sense? Without the legal justification, the decision to fire the missile would not have been made. But that decision-the order to launch the attack - was also critical. So, too, was Judge Bates's decision in the suit to dismiss it on standing grounds. Had he come to a different conclusion, it is possible that the order would never have been made. Is the power to insist on maintaining a claim-right distinguishable from a power to alter it? If exercised, what happens when a competing power to alter it, such as through an exercise of the President's commander-in-chief power, trumps?

And what of Samir Khan's death, or that of Aulaqi's son? They had their claim-rights violated, as would, ostensibly, any number of individuals under the criteria laid out in the DOJ White Paper-both targets and those who happen to be in the proximity of targets or who associate with them. Who has the power to alter their due process or right to life claim-rights? Does it matter that the President, who orders the strike, is elected - or that the cabinet members who add U.S. citizens' names to the kill list are not? The jural relations, adapted from a private law realm, fail to account for both the specificity and the complexity of the legal relations at play in government decisionmaking - even when the most critical of citizens' interests are on the line.

H.L.A. Hart characterizes powers that may be exercised by government officials, ranging from legislative, regulatory, and adjudicatory decisions, to investigation, arrest, and appointment. ${ }^{117}$ There is a distinction to be drawn here between the power to do something that has a direct impact on others, and the ability to bring about changes in legal relations. ${ }^{118}$ But in the case of Aulaki, these distinctions collapse: the decision to place him on the kill list is precisely what altered his due process protections. How we understand the exercise of the powers will depend on the underlying approach to what is meant by a power. ${ }^{119}$

Kramer's assertion that the exercise of a power entails an affirmative decision to act (or to forbear from acting) also is not consistent with the types of new and emerging technologies that are beginning to impact law in profound ways. Sophisticated algorithms, machine learning, and artificial intelligence are being used with legal effect. Criminal risk assessment algorithms, for example, are being employed to determine whether individuals are granted parole, altering their liberty rights. ${ }^{120}$ Predictive policing and geospatial profiling rely on crime maps and artificial intelligence to establish patrol patterns and surveillance of certain neighborhoods, effectively diminishing residents' right to the types of privacy interests encapsulated in the Fourth Amendment. ${ }^{121}$ In June 2012, members of Congress raised concern to President Obama about the

\footnotetext{
${ }^{117}$ H.L.A. Hart, Essays on Bentham (Clarendon Press: Oxford, 1982), 194-198, Essay VIII: "Legal Powers".

118 Andrew Halpin, "The Concept of a Legal Power," Oxford Journal of Legal Studies 16, no. 1 (Spring 1996): 129-52, 131. See also Joseph Raz, "Legal Principles and the Limits of Law, Yale Law Journal, 81 (1972): 823-854, 829 (distinguishing between discretionary power in a given case versus the power granted to the courts generally).

${ }^{119}$ Compare Raz, "Legal Principles"; Neil MacCormick, H.L.A. Hart (1981); and Halpin, "Concept" to Visa AJ Kurki, "Legal Competence and Legal Power," in New Essays on the Nature of Rights, ed. Mark McBride (Oxford: Hart Publishing, 2017), 3147.

${ }^{120}$ Megan Stevenson, Assessing Risk Assessment in Action, 103 Minn. L. Rev. 303 (2018-2019).

${ }^{121}$ See Albert Meijer and Martijn Wessels, Predictive Policing: Review of Benefits and Drawbacks, 42 International Journal of Public Administration, Feb. 12, 2019, https://www.tandfonline.com/doi/full/10.1080/01900692.2019.1575664; Wim Hardyns
} 
continued use of signature drone strikes, in which patterns of behavior suggesting involvement in terrorist activity were sufficient to establish the target for a missile strike. ${ }^{122}$ Targeting decisions implicate the claimright against assault — both for the target and for the person unlucky enough to get into a vehicle with them, or to attend an event where the individual is present, on the day of the attack.

If the feature of decision constitutes the "first feature of legal power," as Professor Andrew Halperin argues, then question arises as to whether any of the decisions above constitute powers. ${ }^{123}$ In each case, a decision was made in relation to the individual whose rights were thereby altered. Hohfeld, though, considers an exercise of a legal power to occur only when "some superadded fact" is "under the volitional control of ... . [a] human being." 124 Yet artificial intelligence and machine learning are being used to ascertain the extent to which claim-rights exist. The determination that an individual is a legitimate target for a drone attack immediately deprives that person of due process rights.

One response that Kramer might offer is to say that the decision to use machine learning is itself the exercise of the power. But this does not seem accurate, as it is in no way individualized in terms of its impact on the individual's claim-rights. Even expanding the assertion to say that the decision implicates members of a particular group (such as prisoners, a particular neighborhood, or members of al-Qa'ida) somewhat begs the question of who falls into that group and thereby has their rights altered-a decision determined by the same entity who has the duty to that individual in the first place. Moving the analysis to the algorithm or the criteria employed does not deflect the critique.

\section{Dignities}

An important weakness in the Hohfeld-Kramer framing is its failure to account for a type of constitutional entitlement that I will refer to as 'dignities.' Anglo-American law has long distinguished between 'alienable' and 'inalienable' rights. By alienable, we mean one of three possibilities: the right-holder can waive the right altogether (which suggests that the right holder has an associated power to waive it); the right holder can assign it to someone else; or the people (a collective) can waive it through constitutional amendment or statutory instrument (depending upon the 'right' in question). Inalienable means the converse: it cannot be waived under any of those circumstances. Numerous political and legal philosophers posit that individuals cannot, under any circumstances, be divested of an inalienable right. ${ }^{125}$ Not only can citizens not divest themselves of such an entitlement, but the existence of such rights does not depend on any written articulation. To the extent, therefore, that a country relies on a written constitution, amending it would not alter the underlying entitlement.

Inalienable rights, not as moral rights but as legal rights, are not properly considered within Hohfeld's first-order pairing. I am not speaking here of natural law, but of recognized entitlements that carry legal force. As a formal matter, they are not claim-rights backed by law, because no written law establishes them. In a common law system, such rights may be recognized by the Courts. But even if the foundational documents were altered, they would still exist. Unlike the other jural relations, there is a temporal progression: inalienable rights are prior to constitution of the state and thus the obligation of the government (which does not yet exist) not to breach them. They do not depend upon ordered society or governmental structures to be called into being.

and Anneleen Rummens, Predictive Policing as a New Tool for Law Enforcement, European Journal on Criminal Policy and Research 24, 201-218 (2018).

${ }^{122}$ Letter from 26 Members of Congress to Barack Obama, President of the United States, June 12, 2012, http://kucinich.house. gov/uploadedfiles/combat_drones_061212.pdf.

${ }^{123}$ Halpin, "Concept," 140.

${ }^{124}$ Hohfeld, FLC, 50.

125 See, e.g., Stuart M. Brown, Jr., "Inalienable Rights," Philosophical Review 64, no. 2 (April 1955): 192-211; Marvin Schiller,

“Are There Any Inalienable Rights?," Ethics 79, no. 4 (July 1969): 312. 
Such was the logic used to decimate the Privileges or Immunities clause in the U.S. Constitution. ${ }^{126}$ At the time the $14^{\text {th }}$ Amendment was adopted, "privileges" and "immunities" were interchangeable with "rights," "liberties," and "freedom" - and had been since Blackstone. ${ }^{127}$ In the Slaughter-House Cases, the Supreme Court famously established that the 'privileges' and 'immunities' protected by the 14th Amendment are limited to those spelled out in the Constitution. They are a function of federal (not state) citizenship. ${ }^{128}$ Thus, while the right might pre-exist citizenship, it is only the codification of the right that gives it legal meaning.

Similarly, in the 1876 case of United States v. Cruikshank, the Court determined that the brutal murder of 160 black citizens outside a Louisiana court house did not violate their (First Amendment) right to peaceable assembly, as the right pre-dated codification in the bill of rights. ${ }^{129}$ It was up to the state to make the determination. Nor was the right to bear arms against the state created by the Second Amendment. ${ }^{130}$ Because of its status as an inalienable right, it could not be enforced through the 14th Amendment. In the decades following Cruikshank, the Court twice underscored that the Privileges or Immunities Clause did not apply to the Second Amendment. ${ }^{131}$ The Court in Heller later observed, "[I]t has always been widely understood that the Second Amendment, like the First and Fourth Amendments, codified a pre-existing right." 132 Once cemented into law, it could be held as against the federal government, but (post-SlaughterHouse) not as a general duty held by states to refrain from interference in the entitlement.

These entitlements reflect the dignity of individuals qua human beings and exist prior to, and contemporaneous with, establishment of the government. And they have legal force. The strength of the natural law discourse means that inalienable rights give meaning to legal relations. Locke's legacy here is hard to deny: drafting the Virginia Declaration of Rights, George Mason asserted, "all men are by nature equally free and independent, and have certain inherent Rights, of which, when they enter into a state of society, they cannot, by any Compact, deprive or divest their posterity; namely, the Enjoyment of Life and Liberty, with the Means of acquiring and possessing property, and pursuing and obtaining Happiness and Safety."133 Less than a month later, Thomas Jefferson echoed his words in the Declaration of Independence. ${ }^{134}$ These documents essentially severed the relationship between Great Britain and the American colonies, with violation of the (inalienable) rights due to colonists serving as the legal grounds on which they were acting. The failure of the Crown to protect those rights (which, in a revisionist claim assumedly were grounded in Magna Carta and the English Bill of Rights) justified rebellion.

One potential response might be to suggest that dignities are (foundational) claim-rights. Ubi ius, ibi remedium, in a democratic society, the electoral process may serve as the only remedy. In extreme cases, recourse may only be had via rebellion. Thus, while inalienable rights, alone, may be unenforceable through a judicial process, the key to redress may nevertheless lay in the hands of the People, who have the attendant power to exercise, or to waive, enforcement. There is a distinction to be drawn between enforceability through the courts and enforceability as what gives a right meaning or existence. A dignity may not be enforceable through the courts; nevertheless, it exists.

\footnotetext{
${ }^{126}$ U.S. Const., amend. XIV ("No State . . s shall abridge the privileges or immunities of citizens of the United States.").

${ }^{127}$ McDonald v. City of Chicago, 561 U.S. 742, 813-14 (2010) (Thomas, J., concurring) (citing and quoting William Blackstone, Commentaries on the Laws of England in Four Books (Philadelphia: Robert Bell, 1771), 1:129).

${ }^{128}$ See Slaughter-House Cases, 83 U.S. (16 Wall.) 36 (1872).

${ }^{129}$ See United States v. Cruikshank, 92 U.S. 542, 552 (1876).

${ }^{130}$ Cruikshank, 92 U.S. at 553.

131 Presser v. Illinois, 116 U.S. 252 (1886); Miller v. Texas, 153 U.S. 535 (1894).

${ }^{132}$ District of Columbia v. Heller, 554 U.S. 570, 592 (2008) (italics in the original).

133 Va. Declaration of Rights, art. 1 (June 12, 1776).

${ }^{134}$ Declaration of Independence, cl. 2 (July 4, 1776) ("We hold these truths to be self-evident, that all Men are created equal, that they are endowed by their Creator with certain unalienable Rights, that among these are Life, Liberty and the pursuit of Happiness.”)
} 
Under this account, can dignities properly be said to be enforceable at all? Recall that one of the defining characteristics of a right is that it be enforceable. Kramer recognizes that the claim-holder does not have to be the one with the discretion to seek enforcement. He or she (or it, in a collective sense) may be in such a position, but so could a person or entity acting as a fiduciary on their behalf, the government, or others. The only requirement, as a definitional matter, is that the claim be enforceable. ${ }^{135}$

Kramer proposes in response to Professor White's challenge to the Correlatively Axiom (i.e., that it fails to take account of ineffectual statutes), that nominal and genuine rights (and their correlative duties) can be distinguished. ${ }^{136}$ The dissimilarity turns precisely on the (un)enforceability of a breach of the correlative duties in question. He writes, "[A]n assertion that a statute imposes duties which are not backed up with effective remedies is equivalent to an assertion that the statute confers rights which are not effectively enforced. Such rights are merely nominal rights rather than genuine rights, but, equally, the duties are merely nominal duties rather than genuine duties." ${ }^{\prime 37}$ Enforced rights are operative, while unenforced rights are inoperative. ${ }^{138}$ To be an operative legal right, for Kramer, one of two conditions holds: either violations of the correlative legal duty are regularly punished or remedied; or violations would be regularly punished/remedied if they regularly occurred. In contrast, if noncompliance with a legal duty seldom (or never) triggers any punitive or rectificatory response, it is an inoperative right. ${ }^{139}$

Kramer identifies two broad categories of inoperative duties: (a) those that are not enforced because the power of waiving enforcement is invariably (or almost always) exercised, and (b) those that are unenforced because of a lack of power to demand their effectuation. In the first category, the right holder, or someone else, has a power to activate punishment if the duty is not performed. ${ }^{140}$ If the power-holder chooses not to exercise the power, she has exercised a legal power of waiver. An additional condition applies: the power-holder must take no action against violations that she can realistically discover. ${ }^{141} \mathrm{~A}$ lack of knowledge that a breach has occurred is not the same as an inability (i.e., a lack of authority) to redress it. In the second category, neither the right-holder nor anyone else holds either the power to enforce the duty or to waive it.

Whether a right is operative centers on whether a duty exists, as well as on the (actual) imposition of punishment and/or a remedy. ${ }^{142}$ The potential for nominal duties arises from the requirement that law must be articulated. ${ }^{143}$ Kramer explains, "Because all or some of the law's demands are presented in written or spoken formulations, gaps can arise between the demands that are expressed and the demands for which legal remedies are available." 144 If legal remedies are not provided for, then the legal requirements are nominal.

Returning to dignities, it may be that the state routinely violates such entitlements, for which no remedy is supplied. History is replete with examples. This doesn't mean that the entitlement had been waivedindeed, one characteristic that distinguishes dignities is that such a power of waiver does not exist. It is outside either the entitlement-holder's hands or the power of the state. Kramer may be right that the ubi ius

\footnotetext{
135 Kramer, RWT, 9.

${ }^{136}$ Kramer, 33-34 (citing White, Rights, 72).

${ }^{137}$ Kramer, 34.

138 Kramer, GRR, 65.

${ }^{139}$ Kramer, 65.

${ }^{140}$ Kramer, 67.

${ }^{141}$ Kramer, 68.

${ }^{142}$ Kramer, 65-66.

${ }^{143}$ Kramer, "Moral Rights," 326.

${ }^{144}$ Kramer, 326.
} 
maxim "is too sweeping in application to legal rights." ${ }^{145}$ Legal rights can be severed from a remedy. ${ }^{146}$ But what happens when a core right is made nominal by its (un)enforceability? The Madisonian electoral check may not always operate, owing to control of state power by certain factions. Does it make any sense to speak of an inalienable right as a claim-right, if the only redress is for a dissolution of government and construction of a new one? Or ought that be considered a different type of entitlement?

Perhaps the answer is that dignities are not claim-rights in a Hohfeldian sense, but, instead, ought to be understood as liberties. A liberty (or privilege), as Kramer notes, says more about the holder of the entitlement and less about the corresponding obligation. Perhaps inalienable rights are more akin to the types of liberties held in a state of nature

Consider due process - one of the oldest entitlements consistently extended in democratic states. In 1215 Magna Carta established, "No free man shall be taken, imprisoned, disseised, outlawed, banished, or in any way destroyed, nor will We proceed against or prosecute him, except by the lawful judgment of his peers and by the law of the land." ${ }^{147}$ English statutory law replaced 'law of the land' with 'due process.' 148 For Blackstone, this clause protected a cluster of 'absolute rights': namely, personal security, personal liberty, and private property. ${ }^{149}$ Personal liberty, for Blackstone, rested on a negative construction: i.e., "the power of loco-motion, of changing situation, or removing one's person to whatsoever place one's own inclination may direct; without imprisonment or restraint, unless by due course of law." 150

The concepts isolated by Blackstone have significant persuasive force in the American context. In 1886, the U.S. Supreme Court used them in the case of Boyd v. United States to find a 'right to privacy' embedded in the Fourth and Fifth Amendments - a right that nowhere appears in the text of the Constitution. In doing so, the Court hearkened back to the principles laid down by Lord Camden in Entick v. Carrington, suggesting that they "affect the very essence of constitutional liberty and security." ${ }^{151}$ These principles "reach further than the concrete form of the case then before the court . . . they apply to all invasions on the part of the government and its employes of the sanctity of a man's home and the privacies of life." 152 The Court continued, "It is not the breaking of his doors, and the rummaging of his drawers, that constitutes the essence of the offence; but it is the invasion of his indefeasible right of personal security, personal liberty and private property, where that right has never been forfeited by his conviction of some public offenceit is the invasion of this sacred right which underlies and constitutes the essence of Lord Camden's judgment." 153

It was because of the existence of the inalienable entitlement that the government was found to have breached its duty to protect Boyd's privacy. Kramer, as aforementioned, points out the shielding effect of claim-rights to liberties. He stops short, though, of suggesting the possibility of liberties as the impetus for the creation of the right: i.e., the existence of a liberty is what motivates the creation of a claim-right. In the case of inalienable liberties, which have no specific legal document as their source, a different type of

\footnotetext{
145 Kramer, 326

${ }^{146}$ Kramer, 326 ("[A]lthough legal rights are often thought to be indissolubly linked to remedies, and although moral rights are often thought to be disseverable from remedies, the truth is precisely the reverse.").

${ }^{147}$ Magna Carta, cl. 39 (1215), in A. E. Dick Howard, Magna Carta: Text and Commentary, rev. ed. (Charlottesville, VA: University Press of Virginia, 1998), 45. In 1225, the Crown reissued the document with minor changes to the provision: "No freeman shall be taken, or imprisoned, or be disseised of his freehold, or liberties, or free customs, or be outlawed, or exiled, or any otherwise destroyed; nor will we not pass upon him, nor condemn him, but by lawful judgment of his peers, or by the law of the land." Edward Coke, The Second Part of the Institutes of the Laws of England (London: 1797), 1:45.

14828 Edw. 3, c. 3 (1354).

149 Blackstone, Commentaries on the Laws, 1:123, 125.

${ }^{150}$ Blackstone, 1:125, 130.

${ }^{151}$ Boyd v. United States, 116 U.S. 616, 630 (1886) (citing Entick v. Carrington, 19 How. St. Tr. 1029 (1765)).

152 Boyd, 116 U.S. at 630.

${ }^{153}$ Boyd, 116 U.S. at 630.
} 
relationship than those laid out by Hohfeld seems to be at play. That is, the claim-right's existence depends on the prior existence and articulation (or recognition) of the liberty.

How should we think about inalienable rights that the Court finds as operable, as against the stateeven where they are nowhere mentioned in the text of the constitution? Is this type of entitlement any different than the 'inalienable rights' considered to be prior to the Bill of Rights and not incorporated in them as against one or more of the sovereign powers? Certainly, there are some entitlements that pre-date the Bill of Rights, whose existence stands as bulwark against the violation of certain other entitlements. The language of the framing document may not call them out by name. They capture a collective legal relation between the People and the Government - even as they hold the power to bring a claim-right into being. It is not the entitlement holder that acts on the liberty (or is able to do so), but the entitlement itself (vis-à-vis the state) that creates the claim-right.

Hohfeld's jural framings also appear to be inadequate for understanding the power to alter the meaning of textual entitlements associated with (and animated by) dignities. In contrast to the unwritten concepts encapsulated in due process, for instance, the text of the U.S. Constitution twice includes the clause 'due process'. The document thus explicitly incorporates Blackstone's 'absolute rights' into the entitlements afforded the People. Related judicial doctrine has evolved in three ways: procedural due process, incorporation of the first eight clauses in the bill of rights (as against the states), and substantive due process.

On the procedural side, the Supreme Court initially rejected efforts to read incorporation of inalienable (procedural) rights into 14th Amendment Due Process clause on the grounds that the rights in question were not sufficiently "fundamental." 154 But over time, that position changed. In 1937, the Court enunciated the due process theory that now incorporates many of the rights in the first eight amendments as against the states. ${ }^{155}$ Justice Benjamin N. Cardozo explained that some of the guarantees are so fundamental that they are "of the very essence of the scheme of ordered liberty" and "neither liberty nor justice would exist if they were sacrificed." ${ }^{156}$ Exactly what is foundational for due process has expanded. ${ }^{157}$

The Supreme Court, with some regularity, 'discovers' fundamental rights in the same written text that previously (ostensibly) did not include them. ${ }^{158}$ How does the Hohfeldian framing account for entitlements explicitly incorporated into the text of the Constitution, and only later understood as housing further, articulable entitlements? As a matter of substantive due process, in Lochner v. New York, the Court unearthed a workers' 'freedom of contract'. ${ }^{159}$ The Court later repudiated its holding, indicating that it would not in the future act with such abandon. ${ }^{160}$ The promise proved short-lived. Broad readings of what constitutes fundamental rights has meant that the Court used textual hooks to protect entitlements nowhere mentioned in the constitution. ${ }^{161}$ Accordingly, in Mapp v. Ohio, the Court determined that the Fourth Amendment encapsulated a 'right to privacy.' 162 In Griswold v. Connecticut, the Court found that a couple's right to using contraceptives stemmed from a penumbra emanating from the First, Third, Fourth, and Ninth

\footnotetext{
${ }^{154}$ See, e.g., Hurtado v. California, 110 U.S. 516 (1884) (grand jury indictment not considered within Due Process); Maxwell v. Dow, 176 U.S. 581 (1900) (12-person jury not considered within Due Process); Twining v. New Jersey, 211 U.S. 78 (1908) (5 $5^{\text {th }}$ Amendment right against self-incrimination not considered within Due Process).

155 Palko v. Connecticut, 302 U.S. 319 (1937).

156 Palko, 302 U.S. at 325, 326.

${ }^{157}$ See, e.g., Grannis v. Ordean, 234 U.S. 385, 394 (1914); Mullane v. Cent. Hanover Bank, 339 U.S. 306, 314 (1950); Benton v. Maryland, 395 U.S. 784, 794-95 (1969).

${ }^{158}$ See e.g., Gitlow v. New York, 268 U.S. 652 (1925) (right to free speech); Near v. Minnesota ex rel. Olson, 283 U.S. 697 (1931) (right to free speech).

${ }^{159}$ Lochner v. New York, 198 U.S. 45 (1905).

160 See West Coast Hotel Co. v. Parrish, 300 U.S. 379 (1937).

${ }^{161}$ See, e.g., Lochner, 198 U.S. 45; Roe v. Wade, 410 U.S. 113 (1973); Lawrence v. Texas, 539 U.S. 558 (2003).

162 Mapp v. Ohio, 367 U.S. 643, 656-57 (1961).
} 
Amendments. ${ }^{163}$ The Court explained in relation to marital privacy, "We deal with a right...older than the Bill of Rights - older than our political parties, older than our school system." 164 The "right to marry' ${ }^{165}$ is considered a fundamental right, as is the 'right to an abortion'"166, and the "right to engage in same-sex intimacy' ${ }^{167}$ Entitlements can thus be discovered - and dismissed - in interpreting the text.

The grounds on which the entitlement is justified as coming within the constitutional remit change. Instead of relying on history and tradition (which, notably, reject these rights), for instance, the Court considers "liberty of the person both in its spatial and in its more transcendent dimensions." 168 Its rationale focuses on unwritten principles that underlie the Bill of Rights. As Justice Anthony Kennedy explains in Obergefell, "The nature of injustice is that we may not always see it in our own times. The generations that wrote and ratified the Bill of Rights and the Fourteenth Amendment did not presume to know the extent of freedom in all of its dimensions, and so they entrusted to future generations a charter protecting the right of all persons to enjoy liberty as we learn its meaning." 169 To find same-sex marriage constitutional, the Court reasoned, "the right to personal choice regarding marriage is inherent in the concept of individual autonomy. [] Like choices concerning contraception, family relationships, procreation, and childrearing, all of which are protected by the Constitution, decisions concerning marriage are among the most intimate that an individual can make." 170

What is the status of unknown entitlements, that, assumedly, exist, but need to be "discovered"? One of the virtues of Kramer's account is that it provides for dynamic rights: the alteration or coming-into-being of rights. But that very alteration, particularly when framed as identifying pre-existing entitlements - when tradition and history emphatically deny them-raises particular problems. The Court, for instance, has concluded that the right to commit suicide is not a fundamental right because tradition, history, and practice doesn't support it. ${ }^{171}$ Nevertheless, there is a "constitutionally protected right to refuse lifesaving hydration and nutrition." ${ }^{172}$ The intervention of a third party is not protected. It is a negative liberty-i.e., the right not to act, but not the right of oneself or other to act. But it was not until 1990 that this entitlement was established, as stemming from a dignity that encapsulates bodily integrity.

\section{Shielding Effect of Dignities}

H.L.A. Hart, looking to general duties, observes how rights may protect the exercise of freedoms. ${ }^{173}$ If two people are walking along and see a coin in the road, each may have a liberty to pick it up, but how they exercise that liberty may be dictated by various duties: they could not, for instance, murder the other person to prevent them from picking up the money, as they would be under a duty to respect the right to bodily integrity. ${ }^{174}$ Kramer, with a nod to Hart's example, emphasizes the shielding effect as one characteristic of

${ }^{163}$ Griswold v. Connecticut, 381 U.S. 479, 484 (1965).

164 Griswold, 381 U.S. at 486.

${ }^{165}$ See Loving v. Virginia, 388 U.S. 1, 12 (1967) (marriage is "one of the vital personal rights essential to the orderly pursuit of happiness by free men.”); Zablocki v. Redhail, 434 U.S. 374 (1978) (right to marry burdened from law prohibiting fathers owing child support from marrying); Obergefell v. Hodges, 576 U.S. 644 (2015) (right of same sex couples to marry). See also M.L.V.

v. S.L.J., 519 U.S. 102, 116 (1996) (noting that the right to marry is a fundamental right under the Due Process clause).

${ }^{166}$ See Roe, 410 U.S. 113.

${ }^{167}$ See Lawrence v. Texas, 539 U.S. 558 (2003) (overturning Bowers v. Hardwick, 478 U.S. 186 (1986)).

168 Lawrence, 539 U.S. at 562.

169 Obergefell, 576 U.S. at .

170 Obergefell, 576 U.S. at .

${ }^{171}$ Washington v. Glucksberg, 521 U.S. 702, 723 (1997) ("We now inquire whether this asserted right has any place in our Nation's traditions. Here ... we are confronted with a consistent and almost universal tradition that has long rejected the asserted right.")

${ }^{172}$ Cruzan v. Director, Mo. Dept. of Health, 497 U.S., 261, 279 (1990).

${ }^{173}$ H. L. A. Hart, “Are There Any Natural Rights?,” Philosophical Review 64, no. 2 (April 1955): 179.

${ }^{174}$ Hart, 179. 
the right/duty and liberty/no-right axis. ${ }^{175}$ It may be that a liberty is coupled with a different right— such as the right to bodily integrity, in which case a physical attack, for instance, on a speaker by $\mathrm{Y}$ would violate a duty not to assault $\mathrm{X}$. This leads Kramer to observe,

one's actions or inactions grounded in liberties are effectively protected - to a considerable extent - by rights that do not pertain specifically to those actions or inactions. Indeed, in almost every situation outside the Hobbesian state of nature, conduct in accordance with a liberty will receive at least a modicum of protection through a person's basic rights. ${ }^{176}$

For Kramer, there is no necessary connection between rights (or duties) and liberties. ${ }^{177}$ An individual can have a right to be free from interference without the underlying liberty to perform that act. ${ }^{178}$ Kramer points to a factory that is dumping waste (which it is not at liberty to do). Should fishermen occlude the pipe, they would interfere with the factory's right to an unimpeded discharge of emissions. ${ }^{179}$ The right to unimpeded flow through the pipes does not entail a liberty to act to send anything through it. Kramer clarifies Hohfeld's scheme by noting that a duty to $\varphi$ does not imply a liberty to $\varphi$, but instead the absence of a liberty to abstain from $\varphi .{ }^{180}$ Similarly, no breach of duty is necessarily implied in a limitation on the privilege. ${ }^{181}$

Nevertheless, the existence of a right gives practical effect to privileges. Kramer writes, "[E]very private actor whose freedom is not a sham must be possessed of legal rights: rights to the exclusion of others from his body and goods, and rights to be given all things that are his due. Now, each person's overall set of entitlements will typically include legal powers of enforcing or waiving many of his rights. Accordingly, each person who is possessed of meaningful freedom can elect to activate the force of the state." 182 Because the very concept of individual autonomy requires that legal rights protect against others interfering with that right, "we can be certain that many of the legal liberties of all or most people in any free-market society will be accompanied by such rights." 183 The collective force of the state ensures the right: "If people try to engage in conduct that violates the owner's rights against interference with the use of his property, then the state will intervene to prevent or punish the outlawed conduct." 184

Dignities appear to act in a similar manner towards claim-rights. In Obergefell, Kennedy explained: "The nature of marriage is that, through its enduring bond, two persons together can find other freedoms, such as expression, intimacy, and spirituality." 185 The right to marry draws "meaning from related rights of childrearing, procreation, and education." ${ }^{186}$ The fact that at no point has the legislature established a claimright via statutory provision matters naught:

The dynamic of our constitutional system is that individuals need not await legislative action before asserting a fundamental right. The Nation's courts are open to injured individuals who come to them to vindicate their own direct, personal stake in our basic charter. An individual can invoke a

\footnotetext{
175 Kramer, RWT, 12.

176 Kramer, 11-12.

${ }^{177}$ Kramer, 14-15.

${ }^{178}$ Kramer, 14; Kramer, RLPP, 416.

179 Kramer, RWT, 16.

${ }^{180}$ Kramer, 17-18 (replying to Sumner, Moral Foundation of Rights, 23, 33).

${ }^{181}$ Kramer, RLPP, 416 ("Moreover, even if the immediate cause of his or her inability to do $\varphi$ is somebody else's conduct, there may well have been no breach of a legal duty involved.").

182 Kramer, In the Realm, 113.

183 Kramer, 115.

${ }^{184}$ Kramer, 113.

185 Obergefell, 576 U.S. at .

186 Obergefell, 576 U.S. at .
} 
right to a constitutional protection when he or she is harmed, even if the broader public disagrees and even if the legislature refuses to act. ${ }^{187}$

Dissenting in Obergefell, Justice Clarence Thomas took the position that what was at stake was a liberty, not a right - a conclusion that carried significant implications. Thomas argued, "Liberty has long been understood as individual freedom from governmental action, not as a right to a particular governmental entitlement." ${ }^{88}$ His objection turned on whether it was a right to governmental recognition of marriage and assignation of benefits thereto, or a freedom of the individual to make vows, hold religious ceremonies recognizing the vows, raise children, and otherwise live with one's partner without interference from the government. ${ }^{189}$

In Hohfeldian terms, Thomas appears to have understood the marriage entitlement to be a liberty/privilege, not a claim-right. In this sense, it was no different from other liberties enjoyed in a state of nature, described by Locke to consist of "perfect freedom to order their actions and dispose of their possessions and persons as they think fit, within the bounds of the law of nature, without asking leave, or depending upon the will of any other man." ${ }^{190}$ That liberty might also be created and recognized by state legislation. But there is no attendant duty on the state to refrain from interference.

If the right to marry is a liberty, which can be altered, then a second-order relation also is in effect: namely, a power to change the privilege. ${ }^{191}$ Two points here deserve notice: first, if there is a power in effect, then the entitlement is alienable, and we are no longer speaking about inalienable rights. Second, in the realm of constitutional law, it is primarily (but not exclusively) the Courts who hold the power. This is very different from pure criminal measures, where legislatures may hold the power to introduce new provisions to protect persons and property. Where constitutional rights are on the line, post-Marbury, the judiciary has the power to alter the liberty. The legislature cannot divest a citizen of a constitutional entitlement established by the judiciary. This is largely a function of judicial review. It holds the upper hand for 'discovering' rights or adjudicating conflict between rights.

It would be wrong, however, to say that the People, or the executive, or the legislature are under a disability in regard to the power. In the United States, some state judges are elected. Federal ones are appointed. Even those constitutionally protected with life tenure can be removed by elected officials. The legislature has to approve appointments to the Supreme Court. Presidential elections have at times turned in significant measure on judicial appointments. Thus, unlike the private law realm, where the exercise of a power entails the absence of a disability on the power-holder's part and the presence of a liability on someone else's part, in the constitutional rights arena, disability is tempered with various structural checks.

Kramer might respond to the lack of clarity about who holds the power by narrowing the power in question. The power to expand liberties to include the right to marry individuals of the same gender might itself carry some sort of qualification on the exercise of that power, subject to structural constraints. But then the understanding of the power itself is being described not in terms of the entitlement, but by prior conditions - which Kramer rejects in the context of jural relations.

\footnotetext{
187 Obergefell, 576 U.S. at .

188 Obergefell, 576 U.S. at (Thomas, J., dissenting) (italics in the original).

189 Obergefell, 576 U.S. at (Thomas, J., dissenting).

${ }^{190}$ John Locke, Second Treatise of Civil Government and a Letter Concerning Toleration, ed. J. W. Gough (Oxford: Basil Blackwell, 1948), 4.

${ }^{191}$ An additional question could be raised here about whether the right to marry is itself a power. An argument frequently raised in support of same-sex marriage centers on the legal entitlements gained through marriage. It is used here in a different sense than the right itself to form a union that is recognized by the state.
} 
Kramer does consider an example provided by Professor David Lyons, in which a right translates into a power to do something, and not just a duty of non-interference held by others. Lyons writes,

Suppose that Alvin is atop a soap box speaking to a crowd against United States military involvement in Vietnam. His act is perfectly lawful, but he is assaulted by some private citizens, driven from the box and silenced. Their behavior is unlawful and constitutes unwarranted and prohibited interference with the exercise of his legal rights. In saying this we may refer to his general right of free speech or to a specific right to stand there addressing the crowd. In either case the right might be construed as a right to do something. ${ }^{192}$

Kramer responds by proposing that in the scenario, Alvin has a liberty, but not a right, to speak. The right in question is a right to be free from assaults — which acts as a shield for the privilege of free expression. ${ }^{193}$ He writes,

Had the citizens been able to silence Alvin without assaulting him or violating any of his other rights, they could have done so. The fact that his speech is 'perfectly lawful' simply means that the government is not entitled to interfere with his discourse. Unless Alvin breaks the law, he (very likely) has a right against governmental interference and an immunity against being stripped of that right. However, such entitlements scarcely mean that private citizens must abstain from interfering with his discourse. ${ }^{194}$

In some sense, then, Kramer is driven back upon claim-rights as a shield for the assertion of liberties. He applies this framing to a range of questions, such as the right not to be tortured. ${ }^{195}$ But to the extent that such rights provide shields, they function not as an inalienable right, but as a right established by law.

\section{Entitlement Creation and the Limits of Powers}

How should we understand shifting interpretation of entitlements captured in constitutional text? What jural relations are prior and consequent to such a determination? Are these relations any different than the powers that mark private law?

For more than 100 years after the invention of the telegraph, the Supreme Court did not recognize any constitutional restrictions on government collection of communications carried on wires. It was not until the 1967 case of Katz v. United States that the Court shifted its Fourth Amendment property-based approach to one centered on the reasonable expectations of both society and the individual engaged in conversation. ${ }^{196}$ That case established the right held by individuals (at least within the United States) to protection against warrantless surveillance for criminal law purposes, and the duty of the government to refrain from infringing that right, outside of a proper warrant procedure (as laid out in the second part of the Fourth Amendment).

If we are to understand the right to make telephone calls without the government listening in to be an (alienable) entitlement, then what brought the claim-right into existence? The answer, as in the same-sex marriage context discussed earlier, is the Court's ruling. In $\mathrm{Katz}$, it was not even the majority's decision that carried the day: Justice Harlan's concurrence became the de-facto standard for ascertaining

\footnotetext{
192 Kramer, RWT, 110-11 (citing and quoting David Lyons, "The Correlativity of Rights and Duties," Noûs 4, no. 1 (February 1970): 49.

${ }^{193}$ Kramer, RWT, 111.

${ }^{194}$ Kramer, 111.

195 Kramer, GRR, 81-89.

${ }^{196}$ See Katz, 389 U.S. 347.
} 
reasonableness under the Fourth Amendment. ${ }^{197}$ Thus, while the majority shifted the focus of Fourth Amendment inquiry from 'places to 'persons', ultimately one justice set the course for determining which rights subsequently followed. That one justice thereby exercised a power-one, ostensibly, available to all nine. What is the jural relation that gave him that entitlement? Is it the power he has by virtue of his exercise of the role of a justice, coupled with facts about the rule of recognition? Or is it the practice of stare decisis, deference by subsequent courts, and acquiescence by the other branches?

The Hohfeldian framing does not capture these types of legal-juridical relationships. The Court (postMarbury) has an entitlement of deference as held against the executive branch, the legislature, and future Courts. It is not just the decision, but the reasoning (or test) articulated by the Court that becomes binding. This is not the same as a duty of non-interference. It is an obligation to act consistent with the principle established by the judiciary. Yet it is not strictly binding. Future justices are free to adopt, or to ignore, the reasoning.

Dissents, too, encapsulate power to bring entitlements - both rights and liberties - into existence. It is not the same as the type of power that Hohfeld identifies, but it is there nonetheless. Constitutional law is replete with examples. Justice John Marshall Harlan's dissent in Plessy v. Ferguson, rejecting segregation, states the "Constitution is color-blind, and neither knows nor tolerates classes among citizens. In respect of civil rights, all citizens are equal before the law." 198 A unanimous Court affirmed his position in Brown v. Board of Education. ${ }^{199}$ Justice Louis Brandeis's famous dissent in Olmstead v. United States similarly became the grounds for the Court's position in Katz. ${ }^{200}$ Justice Scalia's dissent in Lawrence v. Texas undergirded the Court's position in Obergefell, and so on. The same is true in the United Kingdom: in Liversidge $v$. Anderson, Lord Atkins gave a resounding dissent that underscored the power of judicial review over executive action curtailing liberty-a position adopted by the Supreme Court in H.M. Treasury v. Ahmad. ${ }^{201}$

The Court is not, of course, the only actor. The legislature can bring a claim-right into being. Throughout much the $20^{\text {th }}$ Century, the government, citing the President's war power and commander in chief clause, engaged in warrantless surveillance for national security purposes. ${ }^{202}$ In 1972, the Supreme Court rejected the proposition that for matters of domestic security, the executive could unilaterally surveil Americans on U.S. soil. ${ }^{203}$ While some sort of process was necessary, it fell to Congress to institute new rules. The 1978 Foreign Intelligence Surveillance Act subsequently established a special Court to issue orders approving of electronic surveillance within the United States. ${ }^{204}$ Over time, Congress expanded the law to cover the surveillance of U.S. citizens located overseas. ${ }^{205}$ The law affirmatively protects Americans' speech, associative, and religious rights, prohibiting collection premised on otherwise protected First Amendment activities. It also creates a procedure that must be followed by the government to engage in any domestic electronic surveillance, physical search, pen register/trap and trace, or collection of tangible goods for foreign intelligence purposes. Failure to abide by the law carries criminal penalties.

The legislature appears to have the power to bring the entitlement into being. In this case, that entitlement appears to be a claim-right, as the government is under a duty of non-intervention, with criminal

\footnotetext{
${ }^{197} \mathrm{Katz}, 389$ U.S. at 361 (Harlan, J., dissenting).

${ }_{198}$ Plessy v. Ferguson, 163 U.S. 537, 559 (1896).

${ }^{199}$ Brown v. Bd. of Educ., 347 U.S. 483, 493-95 (1954).

${ }^{200}$ Olmstead v. United States, 277 U.S. 438, 471-85 (1928) (Brandeis, J., dissenting); Katz, 389 U.S. 347.

${ }^{201}$ Liversidge v. Anderson [1942] AC 206 (HL); HM Treasury v. Ahmed [2010] UKSC 2 (appeal taken from Eng.).

${ }^{202}$ See Intelligence Activities Senate Resolution 21: Hearings Before the S. Select Comm. to Study Gov't Operations with Respect to Intel. Activities, 7 vols., 94th Cong. (1975) (Church Committee hearings).

${ }^{203}$ See United States v. U.S. District Court, 407 U.S. 297 (1972).

${ }^{204}$ See Foreign Intelligence Surveillance Act of 1978, Pub. L. No. 95-511, 92 Stat. 1783 (codified as amended at 50 U.S.C. §§ 1801-1885c).

${ }^{205}$ See FISA Amendments Act of 2008, Pub. L. No. 110-261, 122 Stat. 2436.
} 
penalties available should the executive overreach and obtain information in violation of the statute. Is the legislature the equivalent of 'the People', acting through elected representatives? Perhaps.

\section{Purported Rights}

The structure of constitutional public law is such that the duty-holder also has the responsibility of enforcement, a situation that is not well-reflected in the Hohfeldian framing and which quickly runs afoul of nemo iudex in causa sua. Under the statute discussed above, for instance (FISA), because of the classified nature of the proceedings and the collection of intelligence, it may only be the government that is aware of transgressions. Yet the government must be the one to prosecute (itself) for any violations. Does it make any sense to say that the duty-holder also has the power to waive the right? Or is this a different kind of jural relationship than one contemplated by Hohfeld? If a duty-bearer can simply waive his duties at will, is the duty-bearer really under a duty to perform (or to refrain from performing) a certain act?

The scenario is not far-fetched: it is precisely the state of affairs that erupted into the public domain in December 2019 with a report issued by the Inspector General of the U.S. Department of Justice. Even though Congress had created a special court to oversee the process of collecting intelligence, the executive had misrepresented information to the court, with the result that the government had routinely broken the law. In his first report, the Inspector General found 17 significant errors, inaccuracies, and omissions in applications related Carter Page, a foreign policy advisor to the Trump Campaign during the 2016 presidential election. ${ }^{206}$ Three months later, a second report focused on 29 applications in which U.S. persons were targeted found errors in every single application, with up to 65 in one case. ${ }^{207}$

The situation is hardly novel. Over the past two decades, the executive branch has repeatedly flouted the statutory language and the prohibitions governing foreign intelligence collection on domestic soil. ${ }^{208}$ Despite the routine violation of FISA - even where the courts have later determined that the statutory violations have breached the Fourth Amendment constitutional rights of the People - the statutory criminal penalties have never been applied. Not a single government employee has ever been charged with violation. The Department of Justice, which is in charge of prosecution, also submits applications for surveillance to the Court.

Kramer appears to deny that such a situation could exist. He writes, "criminal behavior - will hardly be to the liking of the officials who run the legal system wherein the criminal conduct occurs." ${ }^{209}$ His claim, though, rests on three premises: first, that officials know about the conduct; second, that the officials who know about the conduct are not compromised in relation to those who undertook the bad conduct; and third, that rule of law matters. In the realm of national security law, each of these can be challenged. Classified environments are famous for being siloed, with very little information getting in or out - including to those in charge of agencies, much less to prosecutors, who are in parallel roles. Further, there is a conflict of interest inherent in expecting the Department of Justice, which is the entity (mis)representing information to the court (and the agency within which the FBI is housed), to then turn around and prosecute itself for doing so. Moreover, a common argument mounted to defend actions outside the law is that agencies

\footnotetext{
${ }^{206}$ See Office of the Inspector General, U.S. Department of Justice, Review of Four FISA Applications and Other Aspects of the FBI's Crossfire Hurricane Investigation (Washington, DC: DOJ OIG, 2019).

${ }^{207}$ See Office of the Inspector General, U.S. Department of Justice, Management Advisory Memorandum for the Director of the Federal Bureau of Investigation Regarding the Execution of Woods Procedures for Applications Filed with the Foreign Intelligence Surveillance Court Relating to U.S. Persons, (Washington, DC: DOJ OIG, 2020).

${ }^{208}$ See Laura K. Donohue, The Future of Foreign Intelligence: Privacy and Surveillance in a Digital Age (Oxford University Press), 2016; Laura K. Donohue, Section 702 and the Collection of International Telephone and Internet Content, 38(1) Harv. J. of L. \& Pub. Pol'y (2015); Laura K. Donohue, Bulk Metadata Collection: Statutory and Constitutional Considerations, 37(3) Harv. J. of L. \& Pub. Pol'y (2014).

${ }^{209}$ Kramer, GRR, 58.
} 
responsible to public safety may have to flout legal restrictions to keep people safe - an approach that itself eschews the importance of the rule of law.

One response that Kramer might have is that the cluster of associated claim-rights are inoperative, unenforced rights. But it is far from clear how to understand the entitlements in terms of Hohfeld's framing. The power of waiving enforcement is held by the executive and the courts (an example of multiple collectives bearing an obligation). Both have routinely waived it. In a classified world, where a clear conflict of interests exists between the government prosecuting (itself) for violations of the statute, it could also be said that there is no power to demand effectuation. This is particularly troublesome in light of the government's position that it can classify judicial decisions - so that that no one ever can even find out about the violations (or at least those that the court discovers).

Whilst the power to divest exists as a concomitant to the claim-right (and is thus distinguishable from it), the holding of that power by the entity on whom the obligation rests (i.e., the duty-bearer), raises question about the nature of the first-order relation at play in the constitutional realm.

Perhaps what is needed here is a new category altogether: that of 'purported rights', where the enforcement and waiver mechanisms are held by those against whom the entitlement-holder has the right. Underlying the inoperative, unenforced right is a different jural relation: where the duty-holder also has the power of waiver. Central to the Hohfeldian framing is the idea that either the right-holder or someone else who is not the duty-holder has the power of waiver. Nigel Simmonds and other Will Theorists critique Interest Theory on these grounds: i.e., allowing for a circumstance in which all powers of enforcement/waiver are held by the state and its officials. ${ }^{210}$ Kramer acknowledges, "A state of affairs wherein public officials hold all legal powers of enforcement/waiver would grievously distress anyone who values individual latitude and initiative." ${ }^{211}$ But his underlying concern is individual autonomy. In the constitutional public law context, outside of voting new officials into office, significant powers of enforcement are in the hands of the state.

The problem of the duty-holder also determining when a breach can be waived is at times an inescapable aspect of constitutional law. In Bivens v. Six Unknown Named Agents, the U.S. Supreme Court held that a suit alleging violation of Fourth Amendment rights could be lodged against federal officers acting under color of law. ${ }^{212}$ But the Court went on to carve out exceptions: the President of the United States, for instance, and federal officials engaged in adjudicating administrative disputes, are entitled to absolute immunity. ${ }^{213}$ Pari passu, lower courts have ruled Bivens remedies unavailable in circumstances ranging from First Amendment retaliatory prosecution claims to unconstitutional rendition, detention, and torture. ${ }^{214}$ In Vance v. Rumsfeld, the Seventh Circuit, sitting en banc, categorically denied any Bivens remedy for claims of abuse during interrogation by the military. ${ }^{215}$ Assuming, arguendo, that nonfederal remedies do not exist ${ }^{216}$ how should we think about constitutional entitlements in this context?

\footnotetext{
${ }^{210}$ Discussed in Kramer, 60-61

${ }^{211}$ Kramer, 54-55.

212 Bivens v. Six Unknown Named Agents, 403 U.S. 388 (1971).

${ }^{213}$ Nixon v. Fitzgerald, 457 U.S. 731 (1982); Butz v. Economou, 438 U.S. 478 (1978).

${ }^{214}$ Loumiet v. United States, No. 18-5020 (D.C. Cir. 2020) (First Amendment); Lebron v. Rumsfeld, 670 F.3d 540 (5th Cir.) (detention and treatment as an "enemy combatant"); Arar v. Ashcroft, 585 F.3d 559 (2d Cir. 2009) (en banc), cert denied, 130 S. Ct. 3409 (2010) (rendition to Syria); Rasul v. Myers, 565 F.13d 527 (D.C. Cir. 2009 ) (per curiam) (detention in Guantánamo); Doe v. Rumsfeld, 683 F.3d 390 (D.C. Cir. 2012) (treatment by military contractors); Vance v. Rumsfellt, 701 F.3d 193 (7 ${ }^{\text {th }}$ Cir. 2012) (en banc) (military interrogation).

${ }^{215}$ Vance, 701 F.3d at 195.

${ }^{216}$ But see Carlos Manuel Vázquez and Stephen I. Vladeck, "State Law, the Westfall Act, and the Nature of the Bivens Question,” University of Pennsylvania Law Review 161 (2013): 509-583.
} 
Kramer argues that, "Most (though not all) of the entitlements conferred by so-called bills of rights are in fact immunities." 217 The clauses in the First Amendment, for instance, protect certain legal liberties by disabling Congress from restricting or removing them. ${ }^{218}$ Every person in the United States thereby has an immunity vis-à-vis Congress with respect to the free exercise of religion, freedom of speech, freedom of the press, the right of assembly, and the right to petition. ${ }^{219}$ For Kramer, immunities stabilize other legal entitlements. It is "[o]nly because legal rights are almost always accompanied by immunities against most types of divestiture, do they provide solid legal protection against interference or uncooperativeness." 220 The right against bodily harm, for instance, is accompanied by an immunity against others removing this protection. Immunities thus serve as a negative acknowledgement that the right holder is the one with the choice: the jural relation establishing the claim-right cannot be altered by a third party. Simmonds adds that the negative recognition may (or may not) be accompanied by positive recognition (e.g., a power to waive an immunity). ${ }^{221}$ If there is no power to waive it, then the immunity is conjoined with a disability. ${ }^{222}$

How ought we to think about the constitutional rights discourse in this context? Criminal law procedural rights seem to present the clearest example of immunities. The Sixth Amendment right to trial by jury means that individuals are free from any power wielded by others to waive that right. The state is under a disability in regard to suspending it. Any attempt by a prosecutor to exercise such a power would lack legal effect. So, too, in regard to the rights to a speedy and public trial, confront adverse witnesses, and assistance of counsel. Pari passu, the government cannot erode Fifth Amendment protections against double jeopardy or self-incrimination.

The fact that they are held by the People, under the Constitution, as against the Government deprives the Government of the possibility of altering its obligations against the will of the entitlement-holder. Nevertheless, immunity-holders may routinely do precisely that. In public law centered on constitutional rights, where properly assigned as a claim-right, the state (or one of its constituent parts) is always the actor with the correlative duty. Where the People hold an immunity, though, the state in other ways can erode it. It can threaten to bring different charges or to go after family members. It nearly always has access to greater resources than defendants, and it can wield them with devastating affect: loss of liberty, loss of property, and loss of life may all follow. To speak of immunities in the face of overwhelming government power falls short of capturing the relationship that is shaped by certain forms of power.

\section{Concluding Remarks}

Kramer's scholarship advances the analytical value of the Hohfeldian framework. He applies it to the moral realm and tackles its implications for public law. In the process, however, questions arise that challenge whether the pairings capture the types of jural relations that mark constitutional analysis. Such rights, held in res publica by the People, collectives, and citizens, place a corresponding duty on the entitlement holder not to infringe them. They cannot be altered, as they bind society in respect to future generations. They also act as an umbrella over others. In addition, complex collectives constitute the state, increasing the potential for conflict and, in regard to second order relations, making it nearly impossible to identify the power-holder - a situation exacerbated by the advent of new and emerging technologies. Entirely missing from the juridical framing are 'dignities', which are not written and prior to the constitution, but nevertheless binding. By only being enforceable via the electoral process or rebellion,

\footnotetext{
${ }^{217}$ Kramer, RLPP, 417.

218 Kramer, 417.

${ }^{219}$ U.S. Const. amend. I ("Congress shall make no law respecting an establishment of religion, or prohibiting the free exercise thereof; or abridging the freedom of speech, or of the press; or the right of the people peaceably to assemble, and to petition the Government for a redress of grievances.")

${ }^{220}$ Kramer, RLPP, 417.

${ }^{221}$ Simmonds, "Rights at the Cutting Edge," 153.

222 Simmonds, "Rights at the Cutting Edge," 153.
} 
though, they could be considered nominal rights. Nevertheless, they provide an impetus, and shield, for claim-rights. The attendant powers, particularly in relation to written constitutional rights, are complexto say nothing of purported rights, wherein the state's control of enforcement gives rise to a conflict of interest which, when exercised, alter the meaning of a 'duty': the ability to waive one's own obligation, at will, raises question about the extent to which the requirement has meaning and could properly be understood as falling, at all, within Hohfeld's first order relations. 